\title{
Republic of Kazakhstan: Selected Issues
}

This Selected Issues paper for the Republic of Kazakhstan was prepared by a staff team of the International Monetary Fund as background documentation for the periodic consultation with the member country. It is based on the information available at the time it was completed on June 9 , 2005. The views expressed in this document are those of the staff team and do not necessarily reflect the views of the government of the Republic of Kazakhstan or the Executive Board of the IMF.

The policy of publication of staff reports and other documents by the IMF allows for the deletion of market-sensitive information.

To assist the IMF in evaluating the publication policy, reader comments are invited and may be sent by e-mail to publicationpolicy@imf.org.

Copies of this report are available to the public from

International Monetary Fund • Publication Services

700 19th Street, N.W. • Washington, D.C. 20431

Telephone: (202) 6237430 • Telefax: (202) 6237201

E-mail: publications@imf.org • Internet: http://www.imf.org

Price: $\$ 15.00$ a copy

\section{International Monetary Fund Washington, D.C.}





\title{
INTERNATIONAL MONETARY FUND \\ REPUBLIC OF KAZAKHSTAN
}

\begin{abstract}
Selected Issues
Prepared by staff team consisting of Aasim Husain, Hamid Davoodi, Mariusz Sumlinski, Anna Ter-Martirosyan (all MCD), and Peter Lohmus (MFD)

Approved by Middle East and Central Asia Department
\end{abstract}

June 9,2005

Contents

Page

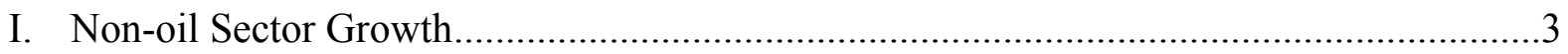

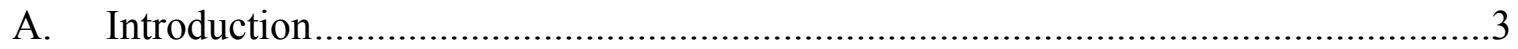

B. Non-oil Growth Trend and Sources of Growth ..........................................................

C. Investment and Labor Market Trends Within the Non-oil Sector ................................7

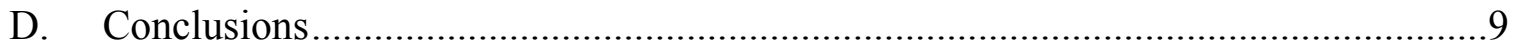

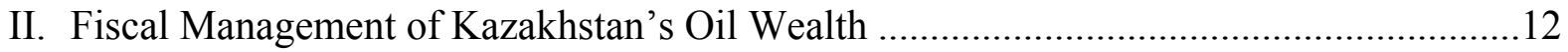

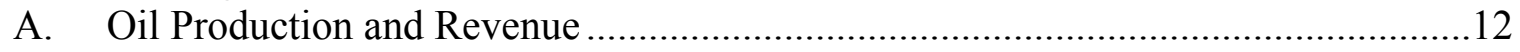

B. The National Fund of the Republic of Kazakhstan.................................................14

C. The Sustainable Non-oil Deficit Path ...............................................................15

D. Implications for the Near-Term Fiscal Stance ………...........................................17

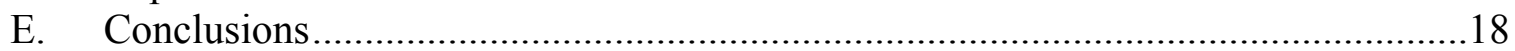

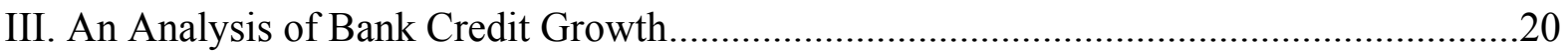

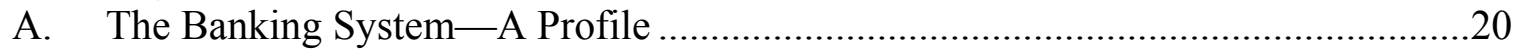

B. Aggregate Credit Growth - Catch up or Bubble?..................................................22

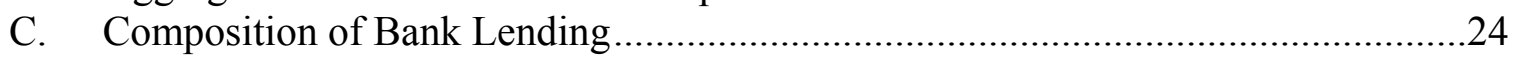

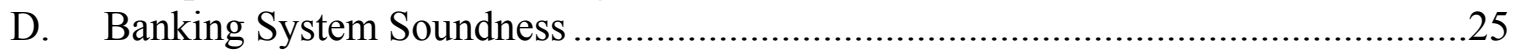

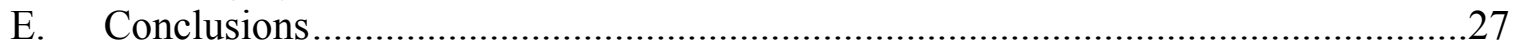

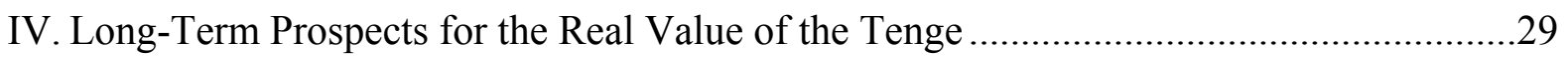

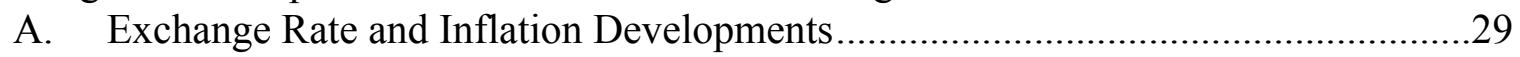

B. PPP and Relative Productivity Differentials...........................................................30

C. Long-run Prospects for the Tenge's Real Exchange Rate ...........................................34

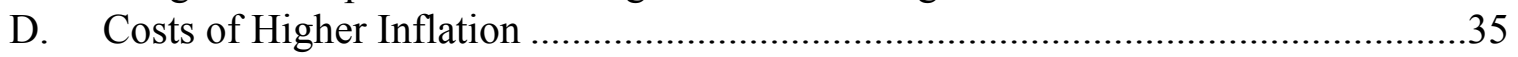

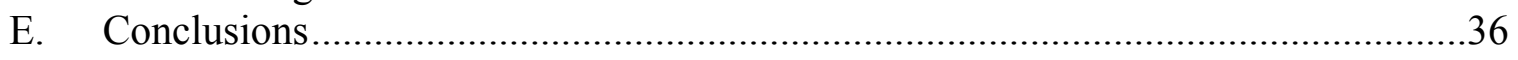


Box

IV.1. Absolute versus Relative Purchasing Power Parity ...................................................31

Figure

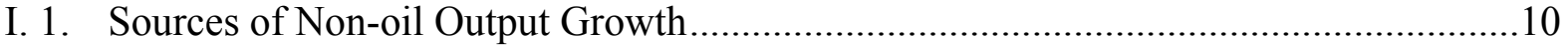

Table

IV.1. Estimated Balassa-Samuelson Effect......................................................................33 


\section{NON-OIL SECTOR GROWTH ${ }^{1}$}

1. The emergence of the hydrocarbon sector as a major engine of growth in Kazakhstan has prompted the authorities to intensify efforts to diversify the economy. To gauge the effectiveness of such efforts, and more generally to assess the performance of the non-oil sector, a clear understanding of what constitutes the oil and non-oil sectors is critical.

This chapter seeks to address the following issues:

- How large is the non-oil sector, and to what extent is this measurement affected by including services that are directly related to hydrocarbon extraction?

- What has been the trend growth rate of non-oil output in recent years?

- $\quad$ How have employment, wage, and investment patterns evolved within the non-oil sector?

\section{A. Introduction}

2. Oil and gas extraction activity has driven overall economic growth over the past decade, although non-oil output has also accelerated in recent years. Hydrocarbon production has more than doubled since 1996. Since 2000, however, the other sectors of economy also started to show significant growth, benefiting from positive knock-on effects of booming oil revenues. Growth in the construction and transportation sectors, where linkages to the oil sector are the most direct, has been particularly rapid.
Output Developments, 1991-2004

\begin{tabular}{lrrr}
\hline & $\begin{array}{r}\text { Average } \\
\text { Growth Rate } \\
1991-95\end{array}$ & $\begin{array}{r}\text { Average } \\
\text { Growth Rate } \\
1996-99\end{array}$ & $\begin{array}{r}\text { Average } \\
\text { Growth Rate } \\
2000-04\end{array}$ \\
& -13.2 & 1.2 & 11.7 \\
\hline $\begin{array}{l}\text { Industry } \\
\quad \text { Of which: }\end{array}$ & -6.9 & 10.1 & 13.7 \\
$\quad$ Oil & 2.3 & 14.4 & 22.9 \\
$\quad$ anatural gas & -8.7 & -0.6 & 3.7 \\
Agriculture & -20.5 & 2.3 & 16.9 \\
Construction & -15.7 & 0.1 & 11.7 \\
Transport and communication & -9.3 & 3.2 & 9.5 \\
Trade and procurement & -9.6 & 0.8 & 10.4 \\
Total & & & \\
\hline
\end{tabular}

Sources: De Broek and Kostial (1998); National Statistical Agency; and Fund staff estimates.

\section{National accounts data, however, tend to understate the true share of the oil} sector in the economy and its contribution to overall growth. A narrow definition of the hydrocarbon sector covers only oil and gas extraction activity. ${ }^{2}$ Thus, all services directly related to extraction - such as construction of extraction facilities and transportation of

\footnotetext{
${ }^{1}$ Prepared by Anna Ter-Martirosyan.

${ }^{2}$ Difficulties in disaggregating oil and non-oil GDP are present, to varying degrees, in most oil-producing economies.
} 
petroleum - are, in effect, placed in the non-oil sector, thereby resulting in overestimation of non-oil activity. A broader measure of the hydrocarbon sector may be obtained by including such services as part of the sector's activity.

4. Sectoral input/output data can be used to estimate the "broad" oil sector, which includes inputs from construction, transportation and other sectors directly related to hydrocarbon extraction. ${ }^{3}$ Inputs from these sectors to oil production were added to the value added by oil extraction activity to construct a "broad" measure of the hydrocarbon sector. At the same time, the contribution of these sectors to non-oil activity was adjusted correspondingly to exclude inputs to oil production activity. The adjustments were significant, representing on average about 40 percent of total value added in the construction sector and 10 percent in the transportation sector.

\section{The adjusted "broad" share of the hydrocarbon sector is significantly larger} than the unadjusted narrow share. In particular, the adjustment for oil-related services implies that the share of hydrocarbons rose from 9 percent of (real) GDP in 1998 to 16 percent in 2004, compared to 3 percent and 5 percent, respectively, under the narrow definition. Correspondingly, the share of the non-oil sector is smaller under the adjustment.

The Non-Oil Sector in Percent of GDP (In 1998 prices)

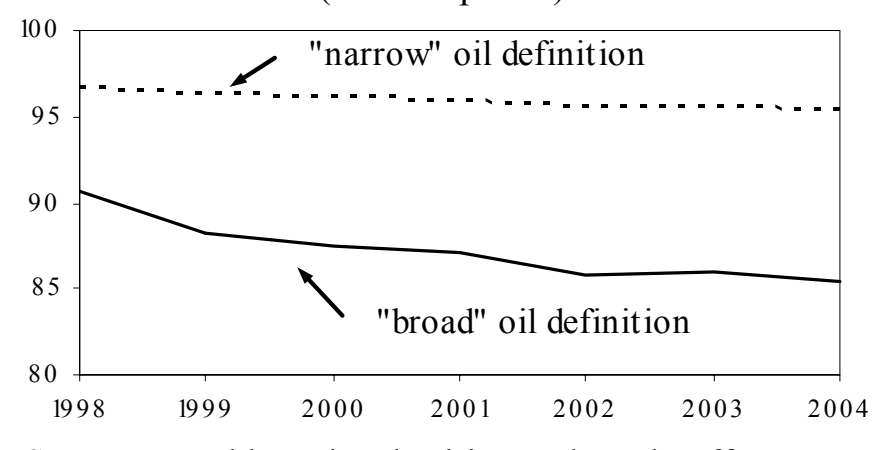

Sources: Kazakhstani authorities; and Fund staff estimates.

\footnotetext{
${ }^{3}$ Other input sectors for oil extraction include trade, real estate, and financial services. The metallurgical industry also provides inputs to the oil sector. The "broad" measure of the oil sector excludes value-added in oil refining, which is primary used for domestic consumption and relatively insignificant in comparison to oil extraction and accounts for about 5 percent of oil-related output.
} 
6. The adjustment for oil-related services activity also implies somewhat lower non-oil sector growth-and faster oil sector growth-in recent years. Real non-oil output growth, after adjusting for oil-related services, has averaged over 8 percent a year since 1998, compared with about 9 percent annually without the adjustment. The component of transportation, construction, and other services directly associated with oil has grown more rapidly than the non-oil related component. For example, real output in oil related

Real Output Growth (In percent)

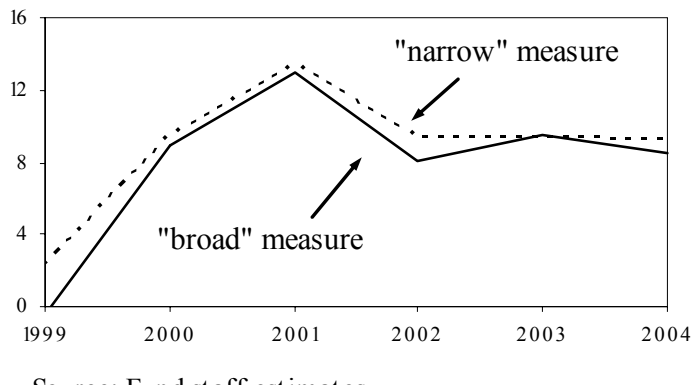

Source: Fund staff estimates. transportation has increased by more than 11 percent a year, on average, compared to about 8 percent for the rest of the transportation sector.

\section{Even with the adjustment, estimated} non-oil sector growth in Kazakhstan compares favorably with that in other CIS economies. While non-oil exporting CIS economies have registered strong GDP growth over the past half decade, non-oil growth in Kazakhstan has consistently exceeded that average. The estimated non-oil output growth paths have been remarkably similar in Kazakhstan and Russia. ${ }^{4}$ This may be related to synchronous cyclical patterns and strong trade links between the two economies.

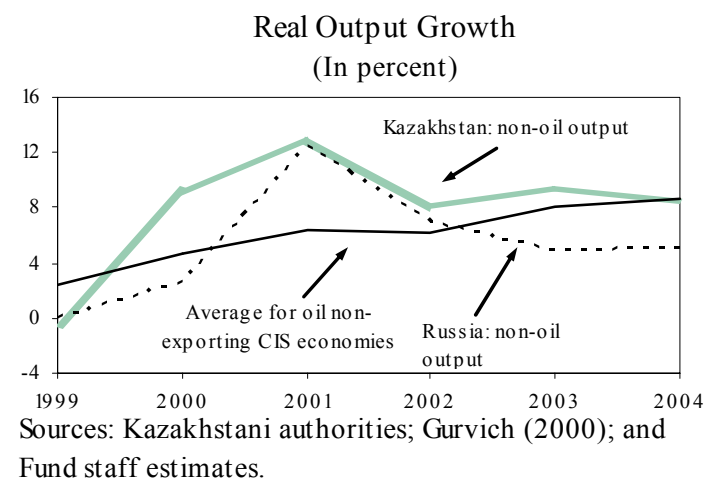

\section{B. Non-oil Growth Trend and Sources of Growth}

8. An assessment of the trend growth rate of non-oil output in recent years is useful in evaluating near-term growth prospects. Results from statistical methods for estimating trends must be interpreted with caution, however, because of the very short data series and the major structural changes that have taken place in the Kazakhstan economy. Moreover, these methods impose a zero output gap on average over the sample period, which, likely, is not appropriate for a transition economy. Nevertheless, such methods provide useful insights.

\footnotetext{
${ }^{4}$ See Gurvich (2004).
} 
9. As noted above, the estimated trend growth rate of the non-oil sector has been around 8 percent over the past half decade. Trend output growth is estimated based on the Hodrick-Prescott (HP) statistical filter over 1998-2004. This sample period was chosen to minimize the impact of structural change, which was greatest during the early 1990 s (the early years of the transition to a market economy). ${ }^{5}$

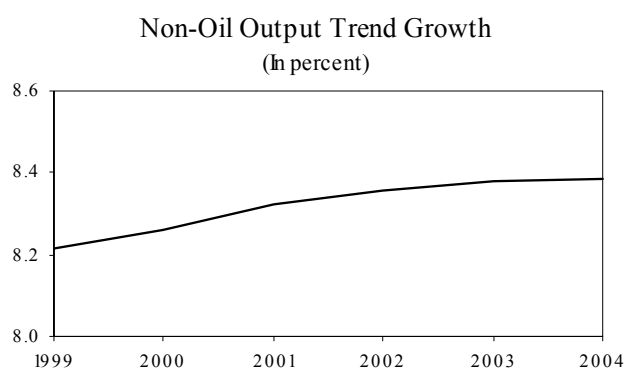

Source: Fund staff estimates.

\section{The non-oil output remained below its} estimated trend level during 1999-2002, but has exceeded it since then. This result,

Non-Oil Output: Deviation from Trend (In percent)

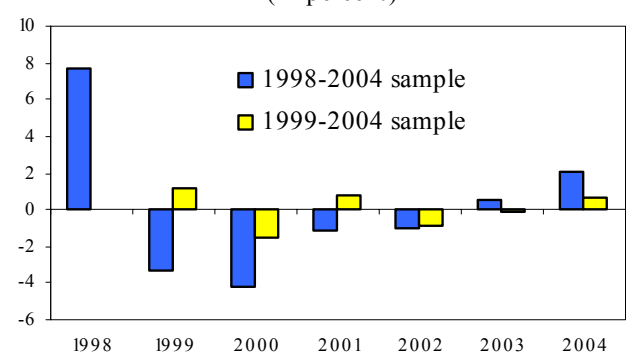

Source: Fund staff estimates. however, is sensitive to the choice of the sample period. Nevertheless, the estimates point to the possible emergence of capacity constraints in recent years.

\section{Growth accounting methods can also shed} light on past growth trends and growth prospects. Non-oil sector growth may be decomposed into components associated with changes in capital and labor inputs, and total factor productivity (TFP). Assuming output $(Y)$ follows a Cobb-Douglas production function with employment $(L)$ and capital $(K)$ as factors of

production, the change in total factor productivity in logarithmic terms is

$$
\mathrm{g}_{\mathrm{TFP}}=\mathrm{g}_{Y^{-}} \alpha \mathrm{g}_{L^{-}}(1-\alpha) \mathrm{g}_{K},
$$

where $\mathrm{g}_{i}$ is the growth rate of variable $i$ and $\alpha$ is the elasticity of elasticity with respect to labor. TFP may be interpreted as a residual that reflects other factors of production and changes in efficiency in the use of factor inputs. Capital stock is calculated according to

$$
\mathrm{K}_{t}=\delta \mathrm{K}_{t-1}+\mathrm{I}_{t},
$$

where $\mathrm{K}$ denotes the capital stock, $\delta$ the depreciation rate, and I investment in period $t .^{6}$

\footnotetext{
${ }^{5}$ Other statistical methods, including linear and exponential filtering, yield very similar results. Sensitivity of the results was also checked by varying the sample period to 1999-2004.
}

${ }^{6}$ Due to unavailability of data on employment and capital stock in the oil sector, non-oil output for this exercise was defined as the total output less value added in the mining sector. 
12. The results indicate that both productivity gains and factor accumulation have contributed to non-oil output growth

(Figure I.1). The average annual productivity growth over the period 1998-2004 is estimated at about 4 percent, in line with findings for other transition economies. The estimated contribution of capital and labor accumulation, however, is considerably stronger than that for other economies. $^{7}$

13. The implications for near-term growth prospects in the non-oil sector are also broadly in line with those obtained with statistical techniques. The growth decomposition indicates a steady decline in the contribution of labor accumulation to overall growth, possibly indicating that the economy is approaching full employment. ${ }^{8}$ Thus, employment growth is likely to contribute much less to overall growth in the future. If TFP and capital accumulation rates remain broadly in line with the recent past, this would suggest overall non-oil sector growth of 6-7 percent a year over the medium term.

\section{Investment and Labor Market Trends within the Non-oil Sector}

14. Non-oil sector investment has increased markedly, although the transportation and communications sector, with the strongest link to the oil industry, accounts for the bulk of the increase. While data on the share of transport and construction investment

The average non-oil growth rate under this definition was 7.1 percent, somewhat lower than the 8 percent under the adjusted "broad" definition noted above, likely on account of the exclusion of metals production from the non-oil sector. Elasticity $\alpha$ and depreciation rate $\delta$ are assumed to be 0.5 and 5 percent, respectively, but alternative calculations for $\alpha \in$ [0.3-0.7] and $\delta \in[3-10]$ percent were also carried out. Labor data were taken as employment in the non-mining sector. Investment data from the National Statistical Agency of Kazakhstan were used to construct a capital stock series. The capital stock data from Chapter II, IMF, Republic of Kazakhstan-Selected Issues and Statistical Appendix (IMF Country Report No. 03/211) were used for the initial period.

${ }^{7}$ Loukianova and Unigovskaya (2004) found the average TFP growth rate for seven CIS countries in 1998-2000 was 4.1 percent and that the average growth rates for labor and capital were 0.6 and minus 0.3 percent. For the non-oil sector in Kazakhstan, based on comparable assumptions for the depreciation rate over the same sample period (1999-2001) as Loukianova and Unigovskaya, the average TFP growth is estimated by staff at 3.4 percent, and the average growth rates for labor and capital at 5 percent and 4 percent, respectively.

${ }^{8}$ The unemployment rate declined from 12.8 percent in 2000 to 8.4 percent in 2004 . 
directly related to the hydrocarbon sector are not available, the higher growth of oil-related transport and construction activities relative to the non-oil portion of these activities suggests that a large part of the increase in investment in these sectors relates to oil. Hence, the increase in "true" non-oil investment is likely to have been smaller than indicated by the aggregate data.

15. Within the non-oil sector, employment growth in nontradables has generally been stronger than in tradables. The rate of employment growth in the oil and other mining sectors (including metals) has been about 8 percent, compared to less than 3 percent for the non-mining sector as a whole. Within the non-mining sector, the shares of the public administration and construction sectors in total employment have grown, while the share of manufacturing has declined significantly. ${ }^{9}$ Interestingly, agriculture's share in total employment rose sharply in the late $1990 \mathrm{~s}$, but has declined in recent years. ${ }^{10}$

\section{Large wage differentials between the mining and non-mining sectors have}

persisted. Average real wages in the mining sector remain close to twice the level of the average wage in the economy as a whole (including the mining sector). Since 2000, however, there has been some narrowing of the gap, mainly on account of rapid wage growth in transportation, trade, and other services.

Wages in Selected Sectors

(In percent of nominal average monthly wages)

\begin{tabular}{lrrrrrr}
\hline & 1999 & 2000 & 2001 & 2002 & 2003 & 2004 \\
\hline Total of economic activities & 100 & 100 & 100 & 100 & 100 & 100 \\
Mining & 208 & 223 & 212 & 197 & 197 & 189 \\
Nonmining & & & & & & \\
Agriculture & 39 & 39 & 40 & 40 & 42 & 42 \\
Construction & 134 & 146 & 155 & 160 & 146 & 136 \\
Manufacturing & 116 & 123 & 115 & 109 & 107 & 107 \\
Transport & 124 & 131 & 141 & 143 & 148 & 147 \\
Financial and real estate services & 130 & 136 & 148 & 165 & 180 & 162 \\
Public service & 95 & 82 & 87 & 83 & 78 & 92 \\
& & & & & & \\
\hline
\end{tabular}

Sources: National Statistical Agency; and Fund staff estimates.

\footnotetext{
${ }^{9}$ The share of manufacturing in total employment has also declined in other transition economies, possibly reflecting an excessively large industrial structure at the start of the transition process.

${ }^{10}$ The large increase in agricultural employment in 2000 is partly due to better measurement of the informal economy.
} 
17. Labor productivity in the non-oil sector has increased almost 5 percent a year on average during 1998-2004. ${ }^{11}$ Productivity growth in the manufacturing sector has been stronger than in other sectors of the economy, reflecting more efficient use of labor. Conversely, labor productivity growth in the agricultural sector has been the weakest, possibly indicating the prevalence of an obsolete capital stock and extensive use of manual labor. Among the other sectors, labor productivity growth in transportation and other services has been particularly strong.
Average Labor Productivity Growth (In percent)

\begin{tabular}{lr}
\hline & 1999-2004 \\
\hline Agriculture & 0.4 \\
Construction & 3.3 \\
Manufacturing & 13.0 \\
Transport & 12.3 \\
Other services & 7.8 \\
\hline
\end{tabular}

Sources: Kazakhstani authorities; and Fund staff estimates.

\section{Conclusions}

18. Adjustments for oil-related services activity reduces the estimated size-and growth-of Kazakhstan's non-oil sector. Even after these adjustments, however, recent growth trends in the non-oil sector have been impressive. Trend-filtering and growth accounting techniques suggest that real non-oil sector growth of 6-8 percent a year can be maintained over the near term. The analysis also indicates, however, that capacity constraints may be emerging, and that the prospect of a major contribution to growth from increased labor inputs has weakened as the economy approaches full employment. Within the non-oil sector, a resource shift toward non-tradable activities appears to be underway. The share of tradables in the non-oil sector has declined significantly, both in terms of value added and employment, while many nontradable activities, especially services and construction, have expanded.

${ }^{11}$ Labor productivity is defined as output (measured in constant 1999 prices) per worker. 
Figure I.1. Sources of Non-Oil Output Growth 1/
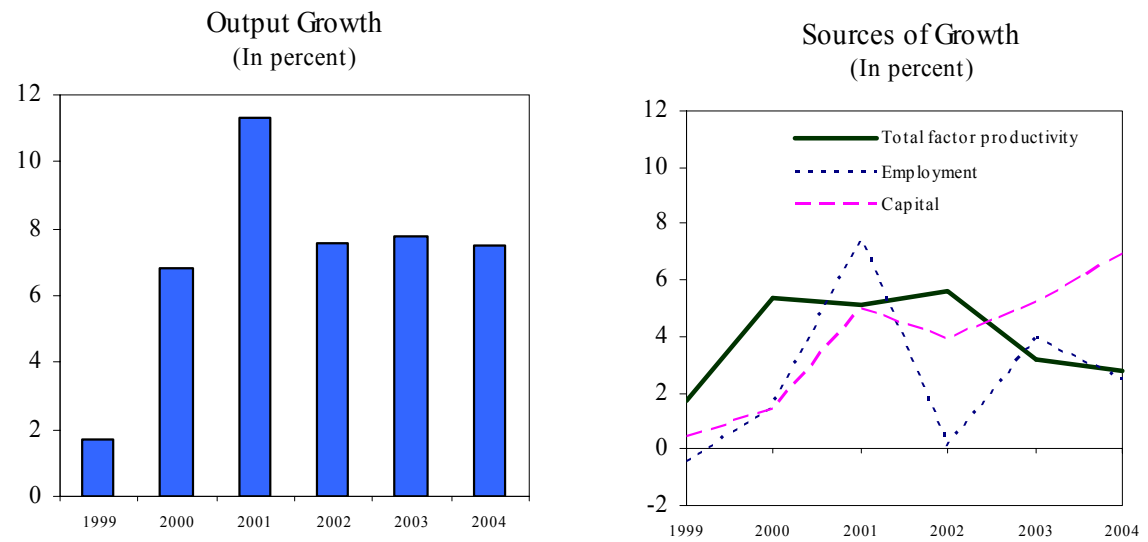

Investment (In percent of GDP)

Investment for Selected Sectors (In percent of total investment)
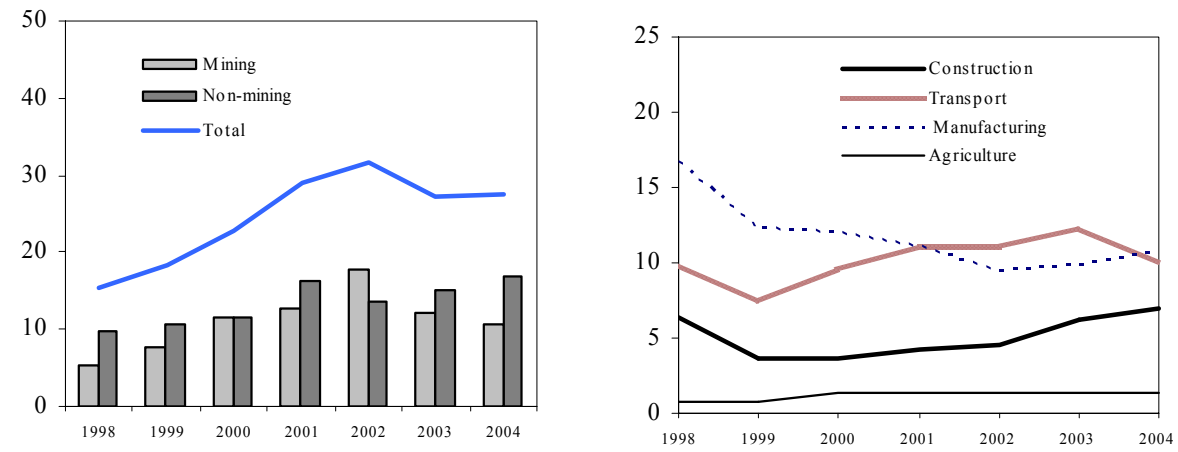

Employment Growth (In percent)

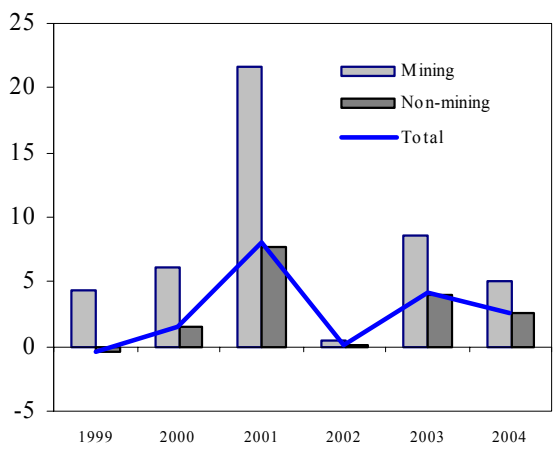

Employment for Selected Sectors (In percent of total employment)

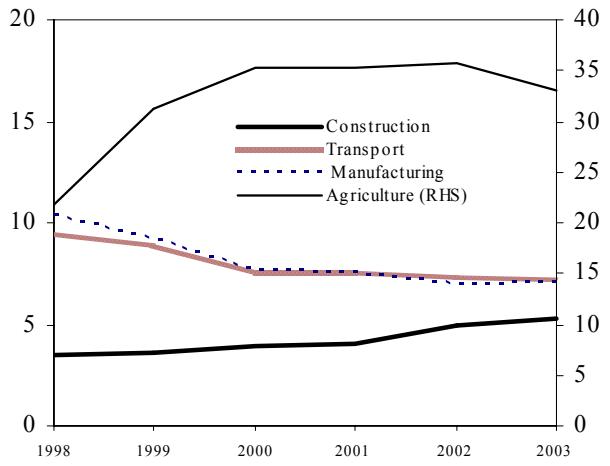

Sources: Kazakhstani authorities; and Fund staff estimates.

$1 /$ Due to data limitations, non-oil output is defined as total output less value added in the mining sector. 


\section{References}

Agency of Statistics of the Republic of Kazakhstan, 2004, National Accounts of the Republic of Kazakhstan (statistical compedium), 1998-2002.

Agency of Statistics of the Republic of Kazakhstan, 2004, Statistical Yearbook of Kazakhstan.

De Broek, M., and Kostial, K., 1998, “Output Decline in Transition: The Case of Kazakhstan” IMF Working Paper 98/45.

Gurvich, E.T., 2004, “A Macroeconomic Estimate of the Role of the Russian Oil-Gas Sector” (in Russian), Voprosy Ekonomiki, No. 10.

International Monetary Fund, 2003, Republic of Kazakhstan-Selected Issues and Statistical Appendix, IMF Country Report No. 03/211.

Loukoianova E., and A. Unigovskaya, 2004, “Analysis of Recent Growth in Low-Income CIS Countries,” IMF Working Paper 04/151.

Oomes N., and O. Dynnikova, 2005, "The Utilization-Adjusted Output Gap: Is the Russian Economy Overheating?," IMF, Draft Working Paper.

Oomes N., and K. Kalcheva, 2005, “Dutch Disease: Does Russia Have the Symptoms?”, IMF, Draft Working Paper. 


\section{Fiscal MANAGEMENT OF KAZAKHSTAN's OIL WeALTH ${ }^{1}$}

1. Higher oil revenue, together with the prospect of a further substantial rise in the future, has permitted a rapid expansion of public spending and a widening of Kazakhstan's non-oil budget deficit in recent years. Although the overall budget remains in surplus, pressures to further increase public expenditure have intensified and the authorities have undertaken to redesign the fiscal strategy for managing the country's oil wealth.

This chapter seeks to address the following questions:

- In light of the prospects for oil production and fiscal revenue for oil, what level of non-oil deficit can be sustained while maintaining oil wealth?

- How does the near-term fiscal stance compare with this "sustainable" level?

- What sort of framework can help ensure that the fiscal stance remains sustainable over the longer term?

\section{A. Oil Production and Revenue}

\section{Oil output and the associated fiscal revenue has increased sharply in recent} years. In 2004, the output of oil and gas condensate reached 59 million metric tons (about 1.2 million barrels per day), increasing about two-fold since 1999 (29.4 million metric tons). In 2004, oil-related activity is estimated to account for about 30 percent of the country's nominal GDP and half of its export earnings. ${ }^{2}$ About 30 percent of total government revenues were derived from the oil sector in 2004, compared to 6 percent in $1999 .^{3}$

\footnotetext{
${ }^{1}$ Prepared by Peter Lohmus.

${ }^{2}$ Chapter I assesses the share of the oil sector in the Kazakhstan economy.

${ }^{3}$ Based on the definition used by Fund staff, oil revenues include the sum of corporate income taxes, royalties, bonuses, and payments from production-sharing agreements.
} 
Oil Production and Revenues

\begin{tabular}{lcccccr}
\hline & 1999 & 2000 & 2001 & 2002 & 2003 & $\frac{\text { Est. }}{2004}$ \\
\hline $\begin{array}{l}\text { Oil production (million metric tons) } \\
\begin{array}{c}\text { Crude oil and oil products export revenues } \\
\text { to total export revenues (in percent) }\end{array}\end{array}$ & 29.4 & 35.4 & 39.3 & 47.3 & 51.3 & 59.4 \\
$\begin{array}{l}\text { Government oil revenues } \\
\text { (in percent of GDP) }\end{array}$ & $\ldots$ & 48.8 & 51.4 & 51.5 & 54.9 & 57.5 \\
\hline
\end{tabular}

Sources: Kazakhstani authorities; and Fund staff estimates.

\section{Oil production and revenues are expected to rise much further over the long} term. Proven and probable oil reserves in Kazakhstan reach 35 billion barrels. Total reserves are estimated at around 50-60 billion barrels, although industry and official estimates vary. ${ }^{4}$ Under the current official scenario, oil production is expected to double by the beginning of next decade, and triple over the next 10-15 years, reaching 3.5 million barrels per day (bpd). Production volumes are then projected to moderate to around 2.5 million bpd by 2030 . The government's oil revenue is expected to grow from $\$ 4.2$ billion in 2005 to about $\$ 16$ billion during 2015-30.

\section{However, the country's oil wealth is associated with significant}

uncertainties. Since much of oil earnings come in the distant future, several potential obstacles - such as inadequate transport capacities, environmental considerations, or technological challenges associated with off-shore drilling - may restrain the realization of the full production potential. ${ }^{6}$ Also, the production projections depend

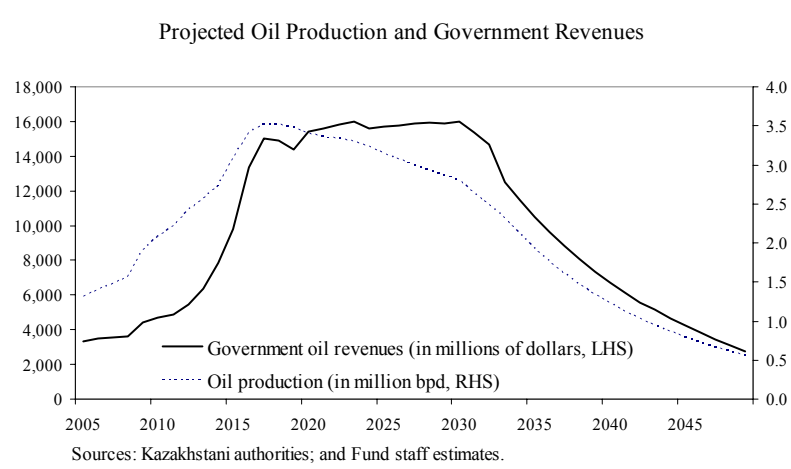
critically on continued sizable foreign investments, which are subject to exogenous shocks.

\footnotetext{
${ }^{4}$ Under the most optimistic scenarios, the Kashagan off-shore field alone may have reserves amounting to more than 50 billion barrels. See Mathieu (2004) for a more comprehensive discussion.

${ }^{5}$ It should be noted that oil extraction and transportation costs in Kazakhstan (up to $\$ 12$ a barrel) are higher than in some other countries, especially in the Middle East, and consequently oil revenue is somewhat lower.

${ }^{6}$ For instance, the introduction of the first phase of the Kashagan off-shore oil field - the largest in the Caspian Sea - was recently postponed by 3 years till end-2008.
} 


\section{B. The National Fund of the Republic of Kazakhstan (NFRK)}

5. The NFRK was established in 2001 to reduce the economic impact of volatile oil prices and to serve as a vehicle for saving part of the oil income for future generations. The rules governing the NFRK are complex and have changed over time. Initially, the authorities identified 12 major companies in the natural resources sector whose fiscal payments were subject to transfer to the NFRK; this list was reduced to 7 petroleum companies in 2004. Flows to the fund consist of a "savings" component equal to 10 percent of budgeted baseline revenue from the listed companies, which is invariant to oil price changes, and a "stabilization" component. The latter includes all revenues from listed companies in excess of receipts that would be realized at a reference oil price, which has remained fixed at $\$ 19$ a barrel. In principle, the NFRK could be drawn down if oil prices fall below the reference price, although this has not happened yet. The authorities have also allocated privatization receipts, special bonus payments, and royalties from certain natural resource companies to the fund. The NFRK is an off-budget fund that is managed by the NBK on behalf of the government. All NFRK assets are invested abroad.

6. A prudent fiscal stance has been maintained. Since the NFRK was established, about 40 percent of the revenue from the oil sector, including one-off bonus payments, has been saved, and the NFRK has accumulated over $\$ 5$ billion in assets. ${ }^{7}$ Nevertheless, the increase in oil revenue has given room to expand public spending, which has increased by 27 percent a year on average during 2000-04. While the share of total spending in relation to GDP has risen only moderately, the share of capital spending has doubled and social spending has also increased.

7. The authorities are in the process of redesigning the NFRK rules. The modifications being studied aim to fully integrate the NFRK with the budget, and devise a rule to guide the use of oil revenue, possibly by linking the non-oil fiscal deficit to the amount of development spending. Development spending, according to the Budget Law, is a key component of the government's programs to increase the longer-term capacity and productivity of the economy, and is in broad terms equal to public capital spending. In this way, the portion of oil revenue to be spent (the non-oil deficit) would be used to enhance the economy's longer-term capacity.

\footnotetext{
${ }^{7}$ By way of comparison, the Norwegian Petroleum Fund (established in 1990), the Alaska Permanent Reserve Fund (established in 1976), and the State Oil Fund of Azerbaijan (established in 1999) have accumulated assets of $\$ 160$ billion, $\$ 29$ billion, and $\$ 970$ million, respectively.
} 


\section{The Sustainable Non-oil Deficit Path}

\section{Since revenues from oil are volatile and exhaustible, an assessment of fiscal} sustainability is challenging. Decisions about spending oil revenues have to be based on assumptions about oil prices, extracting costs, and the time horizon during which exhaustible resources may be depleted. Since most assumptions are likely to be subject to frequent revisions, estimates of the sustainable deficit path need to be updated regularly.

\section{A range of fiscal rules to manage natural resource wealth has been discussed in} the literature. These rules address a variety of trade-offs with regard to expenditure dynamics and intergenerational oil wealth distribution. One extreme is the Bird-In-Hand rule, where only the interest earned on financial assets originating from oil revenues is used for consumption. In this case, the bulk of oil revenue is saved in the early part of the oil extraction cycle, but at the expense of foregone spending with potentially high social and/or economic returns. The other extreme is a rule where all oil revenues are spent, while keeping the overall budget balanced. In this case, fiscal spending is subject to a high degree of volatility, which may lead to undesirable outcomes, and oil wealth is depleted over time. Constant expenditure rules and the Permanent Income Hypothesis (PIH) rule are examples of intermediate rules. Expenditure rules maintain a constant real expenditure stream, either in real terms or in real per capita terms. ${ }^{8}$

\section{Under the standard PIH framework, the value of oil wealth is maintained in real}

per capita terms. In effect, the framework envisages spending the expected income from this wealth, which is the present discounted value of future oil earnings. Roughly, this translates into spending the present discounted value of oil wealth multiplied by the expected long-term rate of earning from this wealth (adjusted for the projected rate of population growth). Then, the non-oil deficit is set equal to such amount. Over time, as the economy grows, the sustainable non-oil deficit will narrow in relation to GDP. 9

\footnotetext{
${ }^{8}$ See, for example, Wakeman-Linn et al (2004) for a discussion of alternative fiscal rules.

${ }^{9}$ The return on financial assets is treated as interest income and not included as oil revenue. See, for example, Barnett and Ossowski (2003) for a discussion.
} 


\section{Key assumptions regarding} future oil production, prices, and other variables are required to assess the sustainable non-oil deficit path. In this chapter, an illustrative baseline scenario is presented, based on WEO assumptions for $2005-10$ and staff projections for 2011-49. Oil production is estimated to peak at 3.5 million bpd in 2017-18, while oil prices are projected to decline to $\$ 40$ per barrel by 2020 ,

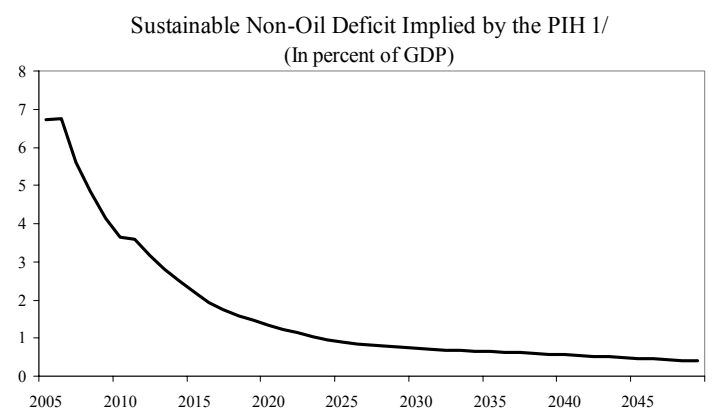

Source: Fund staff estimates. 1/ Non-oil deficit that would maintain oil wealth in real per capita terms. remaining constant in real terms thereafter. The non-oil economy's growth is projected to moderate from about 7-8 percent a year in the near term to an average of 4.5 percent a year over the long term (after 2020).

Assumptions underlying the $\mathrm{PIH}$

\begin{tabular}{|c|c|c|c|c|c|c|c|c|c|c|c|}
\hline & 2005 & 2006 & 2007 & 2008 & 2009 & 2010 & 2015 & 2020 & 2030 & 2040 & 2049 \\
\hline Oil production (in million bpd) & 1.3 & 1.4 & 1.5 & 1.6 & 1.9 & 2.1 & 3.1 & 3.4 & 2.8 & 1.2 & 0.6 \\
\hline Government oil revenues (in billions of tenge) & 538 & 515 & 500 & 481 & 558 & 574 & 1,087 & 1,532 & 1,263 & 529 & 217 \\
\hline Non-oil GDP growth (in percent) & 7.6 & 7.9 & 7.5 & 7.1 & 6.7 & 6.5 & 5.5 & 4.5 & 4.5 & 4.5 & 4.5 \\
\hline 6-m LIBOR on US\$ (in percent) & 3.31 & 4.12 & 4.35 & 4.35 & 4.35 & 4.35 & 4.35 & 4.35 & 4.35 & 4.35 & 4.35 \\
\hline World inflation rate, $\mathrm{CPI}$ (in percent) & 2.1 & 1.9 & 2.1 & 2.1 & 2.2 & 2.2 & 2.0 & 2.0 & 2.0 & 2.0 & 2.0 \\
\hline
\end{tabular}

Sources: Kazakhstani authorities; and Fund staff estimates.

12. Based on these assumptions, the non-oil deficit that maintains oil wealth in real per capita terms is equivalent to $6^{-7}$ percent of GDP in the near term, and declines markedly relative to GDP over the long run. ${ }^{10}$ However, the estimated sustainable path is highly sensitive to changes in the assumptions on oil prices and production volumes. For

Sustainable Non-Oil Defict (PIH) Under Different Oil Price Scenario (In percent of GDP)

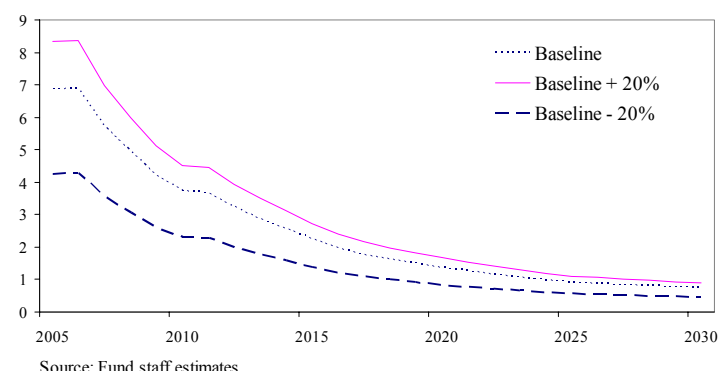

Sustainable Non-Oil Deficit (PIH) Under Different Oil Production Scenarios (In percent of GDP)

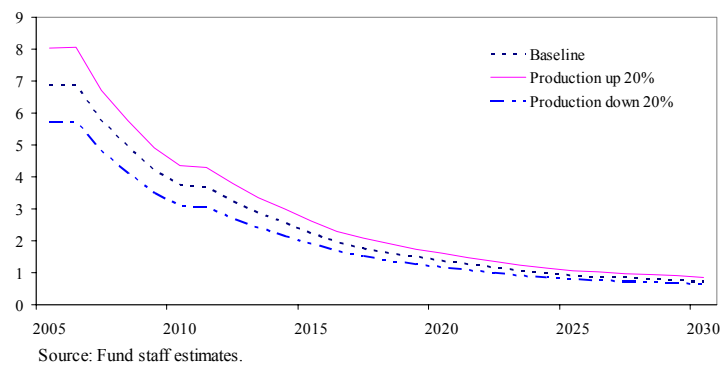

${ }^{10}$ The actual non-oil deficit has widened from 3 percent of GDP in 2002 to 4.7 percent in 2004, but has remained well within the estimated sustainable level for the near term. 
example, a permanent reduction in oil production by 20 percent, starting in 2010, would reduce the average sustainable non-oil deficit for 2005-10 by 1 percent of GDP. Similarly, a permanent decrease in the oil price by 20 percent (relative to the baseline) would reduce the average sustainable non-oil deficit for 2005-10 by about 2 percent of GDP.

13. It should be noted, moreover, that the PIH framework ensures that oil wealth stays constant in real per capita terms over time. If some depletion of oil wealth is judged to be appropriate as economic development proceeds and living standards improve, the implied deficit path would be higher.

\section{Implications for the Near-term Fiscal Stance}

14. Kazakhstan's projected non-oil deficit over the near term is broadly in line with the baseline PIH, but over the medium term it will need to narrow relative to GDP in order to maintain oil wealth at its present level. For 2005, the non-oil deficit is projected at 5.4 percent of GDP, which is well within the sustainable level under the baseline scenario. If oil prices and production move in line with expectations, and other baseline assumptions remain valid, the non-oil deficit will need to narrow to 3-4 percent of GDP over the medium term and to about 1-2 percent of GDP over the longer run.

15. Adoption of a simple fiscal rule can help operationalize the PIH framework and set the overall fiscal strategy. One possibility currently under consideration is to link the non-oil deficit to the amount of budgetary development expenditures. Such a link would be transparent and easily understood. By itself, however, the rule will not ensure that oil wealth is maintained - or that a given target for future oil wealth is met - since the rule under consideration does not provide guidance on setting the level of development spending. ${ }^{11}$ Moreover, such a rule can limit budget flexibility to raise other types of spending that could carry a higher social return. Hence, determining the level of the non-oil deficit in a PIH-type framework, with regular updating, is critical for ensuring sustainability.

16. Another mechanism under consideration could also ensure fiscal sustainability under appropriate parameter choices. Under such a mechanism, the non-oil deficit, which would be financed from oil revenue, would be determined by a formula of the form:

$$
\text { NODef } f_{t}=A+b F_{t-1} \text {, }
$$

\footnotetext{
${ }^{11}$ Strictly speaking, assumptions regarding longer-term growth would need to incorporate the projected effects of public capital spending. If the returns to such expenditures are sufficiently high, they may well permit higher growth of future public spending - because of higher revenue due to faster growth of the economy - within the same non-oil deficit path.
} 
where $F_{t-1}$ represents the outstanding assets of the NFRK at the start of the year. The variable $b$ could be set equal to the expected annual return on NFRK assets over the long term, while $A$ could be fixed in tenge terms for a period of, say, three years. In the near term, when the $A$ term is expected to dominate, this would result in a steady reduction of the nonoil deficit in relation to GDP, consistent with the declining path of the sustainable deficit based on a PIH framework. Of course, sufficient flexibility would need to be retained to be able to alter the formula if oil prices or production prospects change substantially.

\section{E. Conclusions}

\section{Given the prospects for oil production and fiscal revenues for oil, Kazakhstan} can sustain non-oil deficits of over 5 percent of GDP in the near term without reducing the value of oil wealth. This is broadly in line with the fiscal stance projected by the staff on the basis of current policies. However, the sustainable deficit will decline markedly in relation to GDP over the longer term. Moreover, as the analysis illustrates, the sustainable path is very sensitive to unanticipated developments in oil prices, production, reserves, and key macroeconomic variables. In order to ensure that the budgetary position remains sustainable, the fiscal strategy guiding the use of oil revenues will need to be cast within a longer-term fiscal framework and should retain sufficient flexibility to respond to major changes in expectations regarding the value of future oil earnings. 


\section{References}

Barnett, S., and Ossowski, R., 2003, "Operational Aspects of Fiscal Policy in Oil-Producing Countries," in Davis, J.M., Ossowski, R., and Fedelino, A., Fiscal Policy and Implementation in Oil-Producing Countries (Washington: International Monetary Fund).

Davoodi, H.R., 2002, “Assessing Fiscal Vulnerability, Fiscal Sustainability and Fiscal Stance in a Natural Resource Rich-Country," in Republic of Kazakhstan-Selected Issues and Statistical Appendix, IMF Country Report No. 02/64, pp. 7-31 (Washington: International Monetary Fund).

Mathieu, P., 2004, “An Analysis of Kazakhstan's Petroleum Potential,” in Republic of Kazakhstan-Selected Issues and Statistical Appendix, IMF Country Report No. 04/362, pp.17-31 (Washington: International Monetary Fund, 2004).

Thomas, T., and Kissinbay, T., 2004, "Fiscal Rules and Fiscal Sustainability Analysis," in Republic of Kazakhstan-Selected Issues and Statistical Appendix, IMF Country Report No. 04/362, pp.50-63 (Washington: International Monetary Fund).

Wakeman-Linn, J. et al. (2004), Managing Oil Wealth: The Case of Azerbaijan (Washington: International Monetary Fund). 


\section{An ANALYSIS OF BANK CREDIT GROWTH ${ }^{1}$}

1. Kazakhstan's banking sector has expanded rapidly since the late 1990s. Bank lending has grown by about 50 percent per annum in real terms, prompting questions about its sustainability and the potential consequences of a sharp slowdown - or contraction - in credit growth. Against this background, this chapter seeks to address the following questions:

- To what extent is the rapid credit growth in Kazakhstan similar to the type of "catch up" observed in other transition economies?

- What is the sectoral and currency composition of bank lending, how has it changed over time, and how does it compare with other countries?

- What are the key risk exposures of the banking system, and how has the quality of banks' loan portfolios evolved?

\section{A. The Banking System-A Profile}

2. The banking sector in Kazakhstan has undergone substantial consolidation in recent years. There were 35 banks operating in Kazakhstan at end-2004, compared with 71 licensed banks in 1998. The number of bank branches declined as well-from 458 in 1998 to 377 at the end of last year. The three largest banks account for roughly 60 percent of banking sector assets, and foreign banks make up about one third. ${ }^{2}$

3. Interest rate spreads, though generally narrowing, remain high. Lending interest rates, for both local currency as well as foreign currency credits, have declined markedly over the past half decade, reflecting increased competition and, for tenge loans, lower inflation. On the deposit side, foreign currency interest rates have eased in recent years in response to lower global interest rates. Tenge deposit rates offered by banks have also declined as banks' tenge liquidity has increased.

\section{There has been a substantial process of remonetization in recent years,} and deposit dollarization has declined markedly since 2001. The ratio of total bank deposits - tenge as well as foreign currency-denominated-has increased steadily, standing at 23 percent of GDP at end-2004. Deposit dedollarization likely reflects growing confidence in the tenge as inflation declined and the tenge appreciated in nominal terms against the

\footnotetext{
${ }^{1}$ Prepared by Mariusz Sumlinski.

${ }^{2}$ See IMF (2004c) for a detailed analysis of recent developments, including concentration trends, in Kazakhstan's banking sector.
} 
dollar. Deposit dedollarization has also taken place in other transition economies, although the recent pace in Kazakhstan has been more rapid than in other countries. ${ }^{3}$

Interest rates $1 /$

(In percent)

\begin{tabular}{|c|c|c|c|c|c|}
\hline & 2000 & 2001 & 2002 & 2003 & 2004 \\
\hline \multicolumn{6}{|l|}{ Foreign currency } \\
\hline \multicolumn{6}{|l|}{ Institutions } \\
\hline Demand deposits & 0.0 & 1.1 & 1.2 & 1.3 & 1.0 \\
\hline Term deposits & 5.1 & 4.7 & 4.2 & 1.3 & 1.8 \\
\hline Short-term loans & 17.1 & 14.2 & 12.3 & 10.2 & 9.2 \\
\hline Long-term loans & 16.6 & 15.5 & 14.4 & 13.2 & 12.3 \\
\hline \multicolumn{6}{|l|}{ Individuals } \\
\hline Demand deposits & 1.0 & 0.6 & 0.8 & 0.6 & 0.4 \\
\hline Term deposits & 8.3 & 7.7 & 7.1 & 6.1 & 5.8 \\
\hline Short-term loans & 22.4 & 19.9 & 17.2 & 17.0 & 16.6 \\
\hline Long-term loans & 18.9 & 20.3 & 18.7 & 17.2 & 14.9 \\
\hline \multicolumn{6}{|l|}{ Local currency } \\
\hline \multicolumn{6}{|l|}{ Institutions } \\
\hline Demand deposits & 0.1 & 2.7 & 2.7 & 3.2 & 3.1 \\
\hline Term deposits & 6.5 & 5.7 & 5.2 & 4.2 & 3.0 \\
\hline Short-term loans & 19.7 & 17.7 & 15.6 & 15.5 & 14.5 \\
\hline Long-term loans & 17.5 & 16.2 & 15.3 & 15.4 & 14.3 \\
\hline \multicolumn{6}{|l|}{ Individuals } \\
\hline Demand deposits & 2.1 & 1.5 & 1.3 & 1.1 & 0.9 \\
\hline Term deposits & 15.9 & 14.3 & 11.3 & 10.6 & 9.4 \\
\hline Short-term loans & 30.6 & 26.2 & 25.0 & 23.3 & 23.6 \\
\hline Long-term loans & 18.8 & 22.4 & 21.8 & 19.8 & 18.5 \\
\hline LIBOR (1 year) & 6.8 & 3.9 & 2.2 & 1.4 & 2.1 \\
\hline
\end{tabular}

Sources: Kazakhstani authorities; and IFS.

1/ Weighted period average interest rates.

\footnotetext{
${ }^{3}$ See, for example, Havrylyshyn and Beddies (2003) for an analysis of dollarization trends in transition economies.
} 
Bank Deposits

\begin{tabular}{|c|c|c|c|c|c|c|c|}
\hline & 1998 & 1999 & 2000 & 2001 & 2002 & 2003 & 2004 \\
\hline & \multicolumn{7}{|c|}{ (In percent of total deposits) } \\
\hline \multicolumn{8}{|c|}{ Foreign currency deposits } \\
\hline Kazakhstan & 37.0 & 47.2 & 51.0 & 60.5 & 59.9 & 47.1 & 36.2 \\
\hline Russia & 38.0 & 35.8 & 34.6 & 32.6 & 34.4 & 26.6 & 24.8 \\
\hline Ukraine & 39.1 & 43.7 & 38.4 & 32.4 & 32.1 & 32.0 & 36.4 \\
\hline Kyrgyz Republic & 63.4 & 61.7 & 66.1 & 63.4 & 65.7 & 66.8 & 70.3 \\
\hline Hungary & 23.9 & 22.0 & 21.8 & 20.5 & 15.4 & 13.6 & . \\
\hline Latvia & 43.8 & 46.1 & 45.2 & 43.9 & 40.8 & 37.5 & 35.8 \\
\hline & \multicolumn{7}{|c|}{ (In percent of GDP) } \\
\hline \multicolumn{8}{|l|}{ Total Deposits } \\
\hline Kazakhstan & 4.6 & 8.5 & 11.3 & 13.5 & 16.0 & 15.9 & 22.6 \\
\hline Russia & 19.2 & 16.9 & 16.7 & 18.0 & 19.5 & 21.3 & 22.4 \\
\hline Ukraine & 8.1 & 9.4 & 11.0 & 12.5 & 16.7 & 22.9 & 24.0 \\
\hline Kyrgyz Republic & 6.2 & 6.2 & 5.0 & 4.4 & 5.5 & 6.5 & 8.8 \\
\hline Hungary & 38.4 & 39.0 & 38.8 & 39.8 & 40.3 & 40.7 & 40.6 \\
\hline Latvia & 9.3 & 9.1 & 11.5 & 13.3 & 14.6 & 15.5 & 16.7 \\
\hline
\end{tabular}

Sources: IFS; Nicolo (2003); and Fund staff estimates.

5. Bank credit has increased rapidly in relation to GDP, reflecting the ongoing process of financial deepening. While a similar process has taken place in other transition economies, the increase in Kazakhstan's credit-to-GDP ratio has outpaced that in other countries. Credit grew by over 50 percent last year, and by end-2004 the ratio of bank credit to GDP was about 27 percent, significantly higher than in most CIS countries and close to the average level in the EU accession countries.

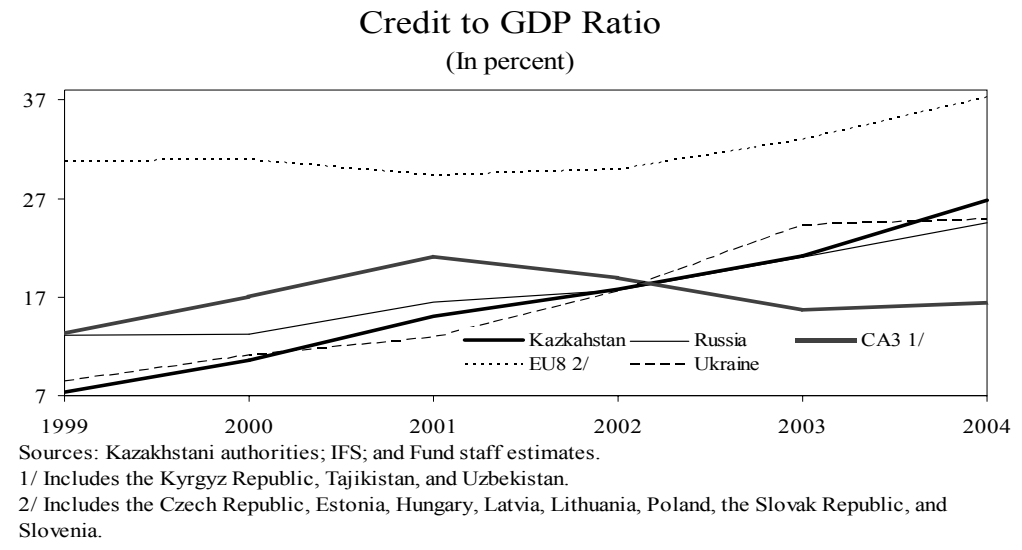

\section{B. Aggregate Credit Growth-Catch up or Bubble?}

6. International experience suggests that excessively rapid credit expansion raises the risk of a subsequent sharp correction, which is usually accompanied by severe economic costs. A recent study_-IMF (2004a) — analyzed credit growth in 28 emerging 
market economies during the period 1970-2002. Among these countries, 18 episodes of excessive credit expansion (or credit "booms") — an expansion that is unsustainable and eventually collapses of its own accord-were identified.

\section{Some features of typical credit boom} episodes in emerging market economies are evident in Kazakhstan. For example, IMF (2004a) found that the median real credit growth in the three years preceding the peak of a typical credit boom was 17 percent. By this measure, credit growth in Kazakhstan has been well in excess of that in the typical credit boom. It should be noted, though, that only one fourth of sustained rapid credit growth

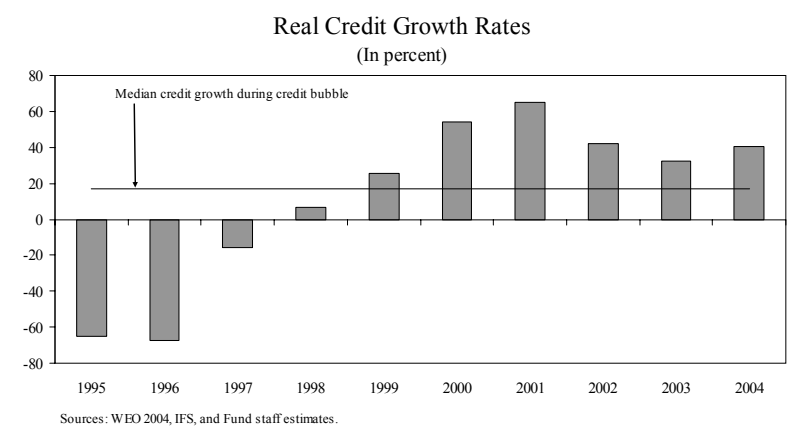
episodes were associated with a subsequent credit collapse.

\section{Other features of the recent credit} expansion in Kazakhstan suggest, however, that the typical emerging market episode is not readily applicable. As noted in IMF (2004a), credit booms in emerging markets typically lasted $3 \frac{1}{2}$ years, with a range of two to five years. In Kazakhstan, as in several other transition economies, credit growth well in excess of the rapid growth threshold for emerging markets has been sustained for six years already. This likely reflects, at least in part, the ongoing remonetization and financial

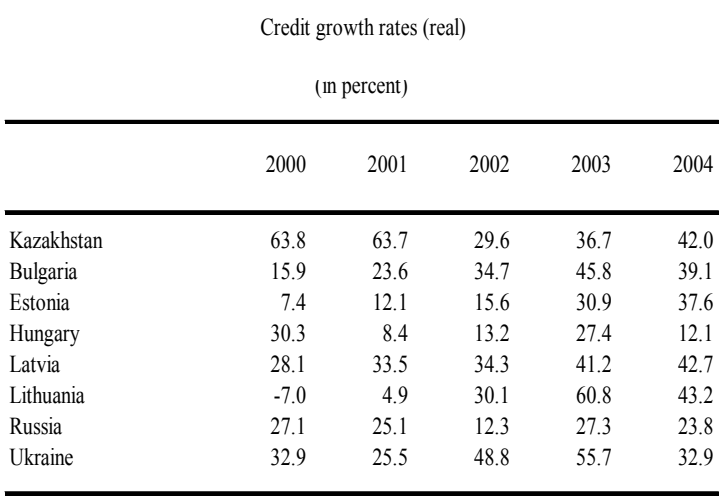
deepening during the transition to a market economy.

\section{In fact, statistical analysis indicates that the} present credit levels in Kazakhstan are broadly in line with the longer-term trend. Application of the Hodrick-Prescott filter to quarterly data over the period 1993-2004 facilitates identification of the trend.

According to this technique, real credit outstanding at end-2004 was actually slightly below the estimated trend level. The steep upward slope of the estimated trend is consistent with the ongoing financial deepening seen in transition economies. This result

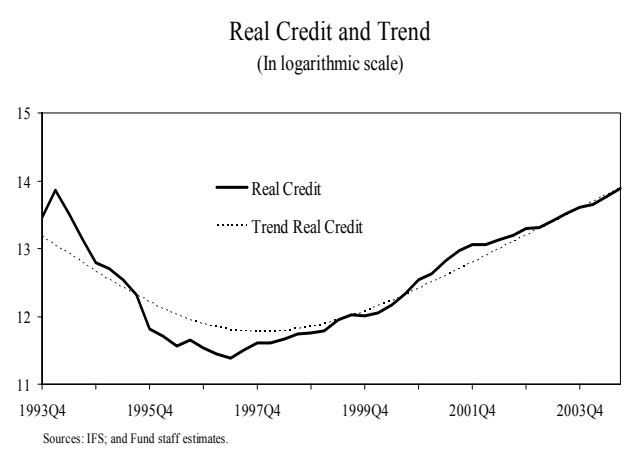

Real Credit and Trend logarithmic scale) 
should be interpreted with caution, however, as it is likely affected by the relatively short time series and the major structural changes that Kazakhstan has undergone over the past decade.

10. Based on the above, it is difficult to make a clear case from aggregate bank lending data that credit growth in Kazakhstan has been "excessive." Nevertheless, sectoral patterns of bank lending - and borrowing - may give rise to increased risk.

\section{Composition of Bank Lending}

\section{Real estate and consumer lending has increased sharply in} recent years. The share of propertyrelated loans in total bank lending rose from about 7 percent in 2000 to 19 percent in 2004, implying increased exposure to property price developments and to the risks associated with a sharp correction in real estate values. ${ }^{4}$ The share of consumer lending also expanded sharply, from about 2 percent to almost 10 percent. By contrast, the shares of the industrial, agricultural, and trade sectors declined substantially, although these sectors experienced, in aggregate, annual growth rates of credit of about 60 percent in nominal terms.

\section{The share of foreign} currency lending in total bank credit, though declining, remains high. The bulk of mortgage loansalmost 90 percent — are foreign currency denominated, possibly reflecting the less attractive interest rates for tenge loans,

\begin{tabular}{|c|c|c|c|c|c|c|c|}
\hline \multicolumn{8}{|c|}{$\begin{array}{l}\text { Foreign Currency Credits } \\
\text { (In percent of total credits) }\end{array}$} \\
\hline & 1998 & 1999 & 2000 & 2001 & 2002 & 2003 & 2004 \\
\hline Kazakhstan & 43.2 & 53.9 & 51.0 & 71.2 & 68.5 & 55.5 & 51.9 \\
\hline Russia & 59.6 & 47.5 & 39.9 & 36.2 & 36.0 & 30.4 & 27.4 \\
\hline Ukraine & .. & .. & 41.4 & 41.3 & 39.5 & 38.5 & 37.4 \\
\hline Kyrgyz Republic & 72.0 & 70.8 & 68.6 & 69.0 & 69.4 & 68.5 & 72.1 \\
\hline Hungary & .. & .. & 41.6 & 37.4 & 36.5 & 39.9 & .. \\
\hline Latvia & 54.7 & 58.6 & 51.7 & 57.0 & 55.2 & 56.5 & 57.1 \\
\hline
\end{tabular}

Sources: Kazakhstani authorities; national authorities; and Fund staff estimates. as well as the strengthening of the tenge in 2003-04. That said, the share of foreign currency lending in Kazakhstan is not out of line with that in other transition economies, and the decline in this share in recent years has been more rapid than in other countries.

\footnotetext{
${ }^{4}$ Property prices have escalated rapidly in 2003-04, particularly in major urban areas.
} 


\section{Banks have also expanded their cross-border lending, mostly in other CIS} countries. Credits to borrowers abroad were equivalent to about 14 percent of banks' total credit operations at end-2004, ${ }^{5}$ compared with less than 1 percent in 2000. Kazakhstan's banks have also bought minority and majority stakes in banks in Russia, Ukraine, Belarus, and the Kyrgyz Republic in recent years.

14. On the liabilities side of their balance sheets, Kazakhstan's banks have become increasingly active borrowers in international financial markets. Banks have borrowed from abroad through syndicated loans, securitization, and issuance of bonded debt. ${ }^{6}$ At end2004, net external liabilities constituted over 35 percent of total assets of the commercial banks, compared with just over 5 percent in 2000 .

\section{Net foreign currency}

denominated assets of the banking system turned negative last year. This likely reflected, at least in part, expectations of continued tenge appreciation. While the potential direct currency mismatch remains relatively small, banks are exposed to indirect currency risk via their foreign currency lending to borrowers with limited (or no) foreign currency earnings.

Net Foreign Currency Assets of the Banking System (In percent of assets)

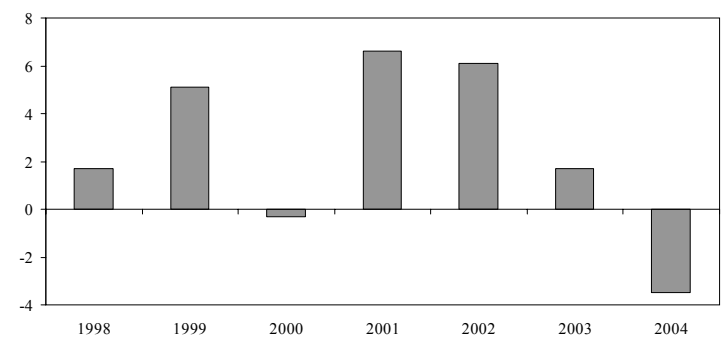

\section{Banking System Soundness}

\section{The banking system's financial position appears sound, but there are some}

potential vulnerabilities. Banks' loan portfolios are relatively young and, for the most part, have not yet been tested by sharp changes in macroeconomic conditions or a severe asset price downturn. The 2004 Update of the Financial System Stability Assessment for

Kazakhstan concluded — on the basis of information through early 2004 - that although the capital adequacy ratio of the banking system seemed comfortable, stress testing revealed potential vulnerabilities, including credit risk and reliance on external wholesale funding. ${ }^{7}$

\footnotetext{
${ }^{5}$ Total credit operations include domestic and foreign credits.

${ }^{6}$ Kazakhstan banks have been active issuers of eurobonds. At present, there are 15 eurobonds on the market issued by the 6 largest banks. All of the bonds were issued in dollars with coupons ranging from 8.125 percent to 10.125 percent, at amounts of $\$ 100$ to $\$ 600$ million.
}

${ }^{7}$ See IMF (2004c). 


\section{Banks remain profitable and well capitalized, and continue to have ample}

liquidity. At end-2004, the average capital adequacy ratio was 15.9 percent, well above the required prudential norm of 12 percent. The banking system's liquidity ratio - measured as liquid assets (mainly t-bills and cash) to short-term liabilities (mainly demand deposits) amounted to over 100 percent, more than three times the minimum requirement of 30 percent. On average, banks' return on assets has ranged from 1 percent to 2 percent over the past six years, and their return on equity from 8 percent to 14 percent.

\section{However, the quality of banks' loan} portfolios has deteriorated somewhat over the past year. Loan losses have increased in relation to total loans outstanding - from about 2 percent at end-2003 to almost 3 percent at end-2004-despite the rapid increase in the volume of outstanding loans. The proportion of classified loans has also risen, from 37 percent to 41 percent, although the bulk of classified loans continue

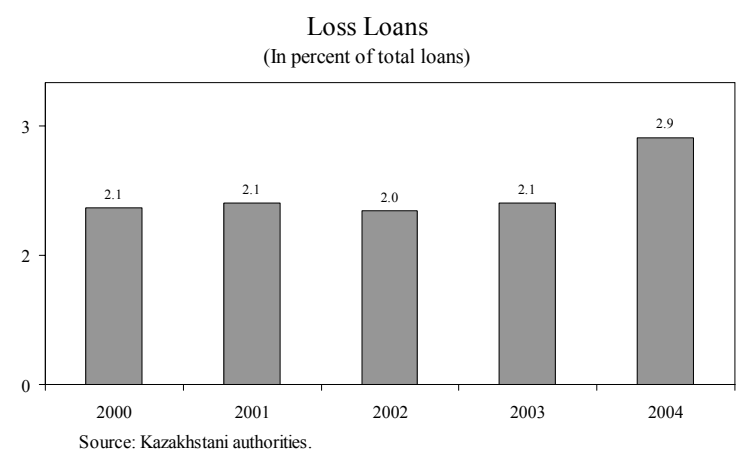
to be serviced on time and banks have set aside increased loan-loss provisions. ${ }^{8}$

Standard and Classified Loans

\begin{tabular}{lccr}
\hline \multicolumn{1}{c}{ Asset category } & $\begin{array}{c}\text { Required provisions } \\
\text { (Percent of asset value) }\end{array}$ & $\begin{array}{c}\text { Portfolio quality } \\
\text { (Percent of total loans) }\end{array}$ \\
\cline { 2 - 4 } & & 2003 & 2004 \\
STANDARD & 0 & 61.1 & 56.2 \\
CLASSIFIED & & 36.8 & 41.0 \\
1. Substandard, payments current & 5 & 25.8 & 31.9 \\
2. Substandard, payments in arrears & 10 & 3.1 & 1.4 \\
3. Unsatistactory, payments current & 20 & 4.6 & 5.3 \\
4. Unsatistactory, payments in arrears & 25 & 1.4 & 1.0 \\
5. Doubttul & 50 & 1.8 & 1.4 \\
LOSS & 100 & 2.1 & 2.9 \\
\hline
\end{tabular}

Source: Kazakhstani authorities.

${ }^{8}$ Loan-loss provisions of the banking system amounted in aggregate to 7 percent of total loans at end-2004, compared with 6 percent at end-2003. 


\section{Substantial cross-relationships between financial institutions and industrial}

groups also heighten concerns. These relationships have contributed to the emergence of financial-industrial groups with holdings in both the banking and real sectors, often under complex ownership structures. While progress has been made in monitoring banks' related party exposures and exemptions from prudential limits on exposure to a single borrower are reportedly no longer granted, continued scrutiny is warranted on related party lending and aggregated large exposures. ${ }^{9}$ More generally, the rapid credit growth environment points to operational challenges for banks, particularly the need to strengthen their internal risk management systems.

\section{E. Conclusions}

20. While credit growth in Kazakhstan has been rapid even by transition economy standards, it is difficult to conclude that such growth has been "excessive" from aggregate data. Recent developments in the pattern of bank lending and borrowing, however, have led to increased exposure to the property sector and international financial markets. Although basic indicators of banks' aggregate financial position appear sound, the moderate deterioration in loan quality over the past year points to the need for continued vigilance.

\footnotetext{
${ }^{9}$ See IMF (2004b).
} 


\section{References}

Bartholomew, P. F., 2004, “Analyzing Credit Quality,” mimeo.

Havrylyshyn, O., Beddies, C. H., 2003, "Dollarisation in the Former Soviet Union: from Hysteria to Hysteresis," Comparative Economic Studies, 2003, vol. 45, pp. 329-358.

International Monetary Fund, 2004a, "Are Credit Booms in Emerging Markets a Concern?" in World Economic Outlook, pp. 103-146, April.

International Monetary Fund, 2004b, "Republic of Kazakhstan: Financial System Stability Assessment - Update including Reports on the Observance of Standards and Codes on the following topics: Banking Supervision and Anti-Money Laundering and Combating the Financing of Terrorism," IMF Country Report No. 04/268, August.

International Monetary Fund, 2004c, "Republic of Kazakhstan-Financial Sector Assessment Program Update-Technical Note-Bank Profitability and Competition," IMF Country Report No. 04/336, October.

Nicolo De, G., Patrick Honohan, and Alain Ize, "Dollarization of the Banking System: Good or Bad?," IMF Working Paper 03/146 (Washington: International Monetary Fund). 


\section{Long-term Prospects for the Real VAlue of The Tenge ${ }^{1}$}

1. Sustained rapid economic growth and a sharp increase in oil export earnings were reflected in a real appreciation of the tenge last year, despite large purchases of foreign exchange by the National Bank of Kazakhstan (NBK). Looking forward, the prospect is for continued rapid growth and a further substantial rise in oil receipts. Against this background, this paper seeks to address the following issues:

- Is the real appreciation of the tenge an equilibrating phenomenon that is expected to persist over the longer term?

- To the extent that real appreciation is inevitable and the tradeoff is between nominal appreciation and higher inflation, what considerations are relevant for determining the appropriate rate of inflation for Kazakhstan over the medium term?

\section{A. Exchange Rate and Inflation Developments}

2. The tenge has strengthened markedly in real terms against the U.S. dollar over the past half decade. Since 2000 , the tenge-dollar real exchange rate- the nominal exchange rate adjusted for changes in the consumer price index (CPI) in both countries - has appreciated by some 28 percent, with most of the appreciation occurring in 2003-04. A large part of the real appreciation took place through higher inflation-Kazakhstan had a cumulative inflation differential of about 17 percent with the United States during 2000-04-but nominal appreciation (about 12 percent on a cumulative basis) also played a role.

3. By contrast, the tenge has depreciated in real terms against the ruble, its largest trading partner currency, although this trend was reversed last year. During 2000-04, Russia's inflation rate exceeded that of Kazakhstan by a cumulative 32 percent, while the tenge appreciated in nominal terms vis-à-vis the ruble by 11 percent. As a result, the tenge's cumulative real depreciation against the ruble amounted to about 17 percent over the period.

4. In trade-weighted (effective) terms, the real external value of the tenge has remained broadly flat. This follows a sizable real effective appreciation in the mid-1990s, possibly reflecting an "initial undervaluation" that appears to have characterized the real exchange rates of many transition economies, and an equally sizable real effective depreciation in the aftermath of the Russian crisis in 1998-99. However, measurement of Kazakhstan's real effective exchange rate (REER) is complicated by the large share of oil in Kazakhstan's external trade and the substantial changes in trade shares with key partners since the transition to a market economy commenced. Hence, the weights assigned to

\footnotetext{
${ }^{1}$ Prepared by Hamid Davoodi.
} 
Kazakhstan's REER in the Fund's Information Notice System (INS) - for example, 45 percent for Russia and 3 percent for the U.S.- - are subject to significant error and the analysis below focuses on the real value of the tenge against the U.S. dollar.

Real Exchange Rate of the Tenge

$(1995=100)$

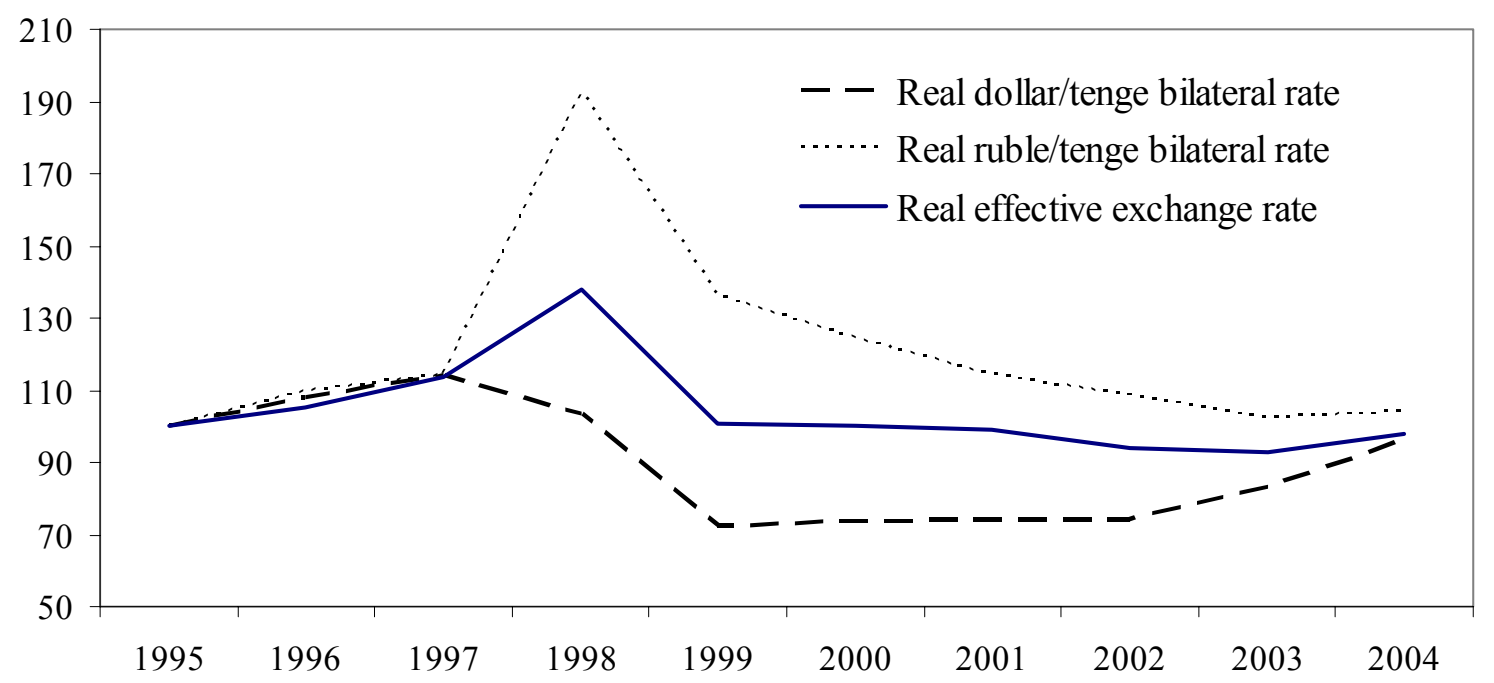

Source: INS; and Fund staff estimates.

\section{B. PPP and Relative Productivity Differentials}

5. International comparison of price levels is one way of assessing the deviation of a country's real exchange rate from its long-run level. The theory of Purchasing Power Parity (PPP) holds that prices of an identical consumption basket should be the same in all countries once expressed in a common currency (see Box IV.1). While departures from PPP can be large and narrow only very gradually, they are indicative of the direction of future real exchange rate developments - toward the equilibrating long-run PPP level - in the absence of other shocks.

6. The comparison of CPI levels across countries needs to account for the presence of nontraded goods and differences in consumption baskets. Nontraded goods - whose prices need not equalize across countries - constitute a sizable share of the overall consumption basket, and nontradables prices tend to be higher in countries with higher wages and incomes. Hence, the relative price of tradables to nontradables - the real exchange ratewill tend to be higher in countries with greater per capita income. 


\section{Box IV.1. Absolute versus Relative Purchasing Power Parity}

The theory of PPP predicts that the relative price of a common basket of goods between two countries measured in a common numeraire, the real exchange rate, should be equal or equalize quickly following a shock to the long-run relative price. Thus the real exchange rate $(q)$ between two countries under the absolute version of PPP is defined as follows:

$$
q=\frac{p}{e \times p^{*}} \quad \text { and } \quad q=1
$$

where $p, e$, and $p^{*}$ are the home country price level measured in home country currency, the nominal exchange rate, defined as price of foreign currency in terms of home currency, and the foreign price level measured in its own currency. Thus, absolute PPP means that the purchasing power of a unit of domestic currency is exactly the same as in foreign economy, once it is converted to foreign currency at the absolute PPP exchange rate.

The PPP theory has the following implications:

- In the short to medium run, the home country can experience a real appreciation of its currency if $q$ rises and deviates from 1, which can happen through either a higher domestic price level, a nominal appreciation (a lower $e$ ), a lower foreign price level, or all of the above. Since the home country has no influence on the foreign price level, movements in the latter are assumed to be exogenous.

- $\quad$ This absolute version of PPP is often contrasted with relative PPP, a weaker version of the theory, which requires that only changes in national price levels be equal, implying zero inflation differentials when using the same numeraire. Hence, changes in the real exchange rate must be zero or tend towards zero in the long run following a shock. Thus, relative PPP holds when inflation differentials between two countries are fully offset by nominal exchange rate changes.

- $\quad$ CPI-based measures of the real exchange rate use indices that are constructed relative to a base year. They therefore measure the rate of change of the price level from the base year and not its absolute level.

\section{7. $\quad$ According to the Balassa-Samuelson effect, the long-run real exchange rate} changes over time in response to relative productivity differentials. Countries with higher productivity growth in the tradables relative to the nontradables sector tend to experience real appreciation (increase in the relative price of nontradables to tradables). In essence, higher tradables productivity pushes up wages in the tradables sector, which leads to higher wages in the nontradables sector and, consequently, to higher nontradables prices. Since tradables prices are set in international markets and do not respond to domestic market conditions, the relative price of nontradables to tradables rises. As the overall (consumer) price level is a weighted average of tradables and nontradables prices, the higher price of nontradable goods leads to an increase in the overall CPI. Moreover, assuming that real per capita GDP differentials across countries are a reasonable proxy for relative productivity differentials, ${ }^{2}$

${ }^{2}$ Due to lack of data on sectoral productivity, inconsistencies across countries in definition and coverage of nontradable and tradable sectors, and difficulties in choosing appropriate 
the Balassa-Samuelson effect implies a positive correlation between relative income levels and the real exchange rate. It also suggests that as a country's (relative) income level rises over time, its real exchange rate will appreciate. ${ }^{3}$

\section{Analysis of cross-country data-with the necessary adjustments for comparison purposes - suggests that the tenge was significantly undervalued in real terms in} relation to its estimated long-run PPP level in 2000. The data-obtained from Penn World Tables (PWT) — compare the U.S. dollar prices of an identical, quality-adjusted output basket among a large number of countries. As the chart indicates, there is indeed a correlation between countries' real exchange rate and their income level. The vertical distance from a country's actual position to the estimated regression line - which provides an estimate of the long-run real exchange level—measures the deviation of the actual real exchange rate from its long-run value.

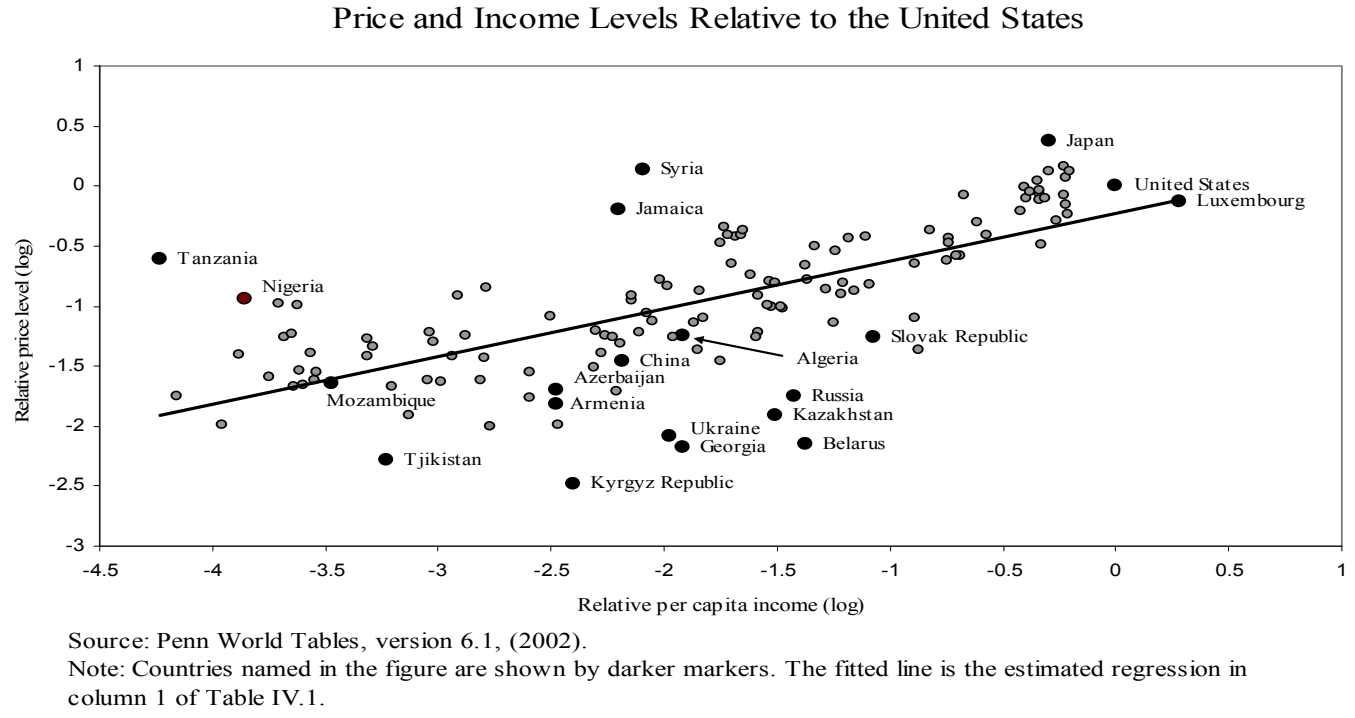

sectoral price deflators, cross-country tests of the Balassa-Samuelson effect often use the real per capita GDP differential taken from PWT as a proxy for the productivity differential. This is a reasonable proxy, as many studies have shown that total factor productivity accounts for much of the cross-country variation in per capita income levels (e.g., Aiyar and Dalgaard, 2005). See also Choudhri and Khan (2004) for a novel attempt at creating productivity data for a sample of 16 developing countries over the 1976-94 period. This study also highlights the pitfalls inherent in measuring sectoral productivity and the relative price of nontradable goods for developing countries when testing for the Balassa-Samuelson effect.

${ }^{3}$ A number of studies have found empirical support for the Balassa-Samuelson effect. See, for example, Froot and Rogoff (1994), Taylor and Taylor (2004), and Frankel (2005). See Edwards and Savastano (1999) and Bergin, Glick, and Taylor (2004) for a review of the Balassa-Samuelson effect. 
9. As the chart indicates, Kazakhstan's actual real exchange rate was $\mathbf{3 4}$ percent below its estimated long-run PPP level in the year 2000, implying an undervaluation of 66 percent. Other countries with significant undervaluation include China, oil-exporting countries such as Russia, Azerbaijan, and Algeria, and other transition economies such as the Kyrgyz Republic and Tajikistan. ${ }^{4}$ Many of Kazakhstan's major trading partner currenciesnotably the Russian ruble, Chinese renminbi, and Ukrainian hryvnia — also appear to be undervalued in relation to their estimated PPP level.

\section{Updated estimates of the Balassa-Samuelson effect were obtained by staff. As} depicted in the chart, an OLS cross-section regression of relative prices on relative real per capita GDP for 133 countries, where both variables were measured in relation to the United States yields results indicating strong presence of the Balassa-Samuelson effect (Table IV.1). The estimated coefficient in the table shows that a one percent increase in a country's real per capita GDP (relative to the U.S.) is associated with a real appreciation (against the US dollar) of about 0.4 percent. ${ }^{5}$

Table IV.1. Estimated Balassa-Samuelson Effect

Dependent variable: Log (relative price level)

\begin{tabular}{|c|c|c|c|c|c|c|c|c|}
\hline Explanatory variables & $\begin{array}{r}2000 \\
(1)\end{array}$ & $\begin{array}{r}2000 \\
(2)\end{array}$ & $\begin{array}{r}1995 \\
(3)\end{array}$ & $\begin{array}{r}1990 \\
(4)\end{array}$ & $\begin{array}{r}1990 \\
(5)\end{array}$ & $\begin{array}{r}1985 \\
(6)\end{array}$ & $\begin{array}{r}1980 \\
(7)\end{array}$ & $\begin{array}{r}1960 \\
(8)\end{array}$ \\
\hline Constant & $\begin{array}{c}-0.232 * \\
(-3.06)\end{array}$ & $\begin{array}{r}-4.159 \\
(-15.48)\end{array}$ & $\begin{array}{l}\cdots \\
\cdots\end{array}$ & $\begin{array}{r}-3.3988^{*} \\
(-9.39)\end{array}$ & $\begin{array}{r}0.035 \\
(0.389)\end{array}$ & $\begin{array}{l}\cdots \\
\cdots\end{array}$ & $\begin{array}{l}\cdots \\
\cdots\end{array}$ & $\begin{array}{r}0.49 \\
\ldots\end{array}$ \\
\hline Log (relative per capita GDP) & $\begin{array}{c}0.394 * \\
(11.35)\end{array}$ & $\begin{array}{c}0.382^{*} \\
(12.29)\end{array}$ & $\begin{array}{c}0.410^{*} \\
(10.25)\end{array}$ & $\begin{array}{r}0.317^{*} \\
(7.44)\end{array}$ & $\begin{array}{r}0.366^{*} \\
(8.71)\end{array}$ & $\begin{array}{r}0.200 * \\
(6.75)\end{array}$ & $\begin{array}{r}0.200^{*} \\
(4.00)\end{array}$ & $\begin{array}{l}0.51 * \\
(8.33)\end{array}$ \\
\hline Adjusted R-squared & 0.492 & 0.566 & $\cdots$ & 0.323 & 0.420 & $\cdots$ & $\cdots$ & $\cdots$ \\
\hline F-Statistic & 128.887 & 151.14 & $\ldots$ & 55.33 & $\ldots$ & $\ldots$ & $\ldots$ & $\ldots$ \\
\hline P-value & 0.000 & 0.000 & $\ldots$ & 0.000 & $\ldots$ & $\ldots$ & $\ldots$ & $\ldots$ \\
\hline Number of observations & 133 & 118 & 142 & 118 & over 100 & 118 & 118 & 12 \\
\hline
\end{tabular}

Sources: Column (1): Staff estimates; column (2) and (4): Frankel (2005); Column (5): Rogoff (1996); Columns (3), (6) and (7):

Bergin, Glick and Taylor (2004); column (8): Balassa (1964)

* denotes statistical significance at 1 percent level.

The numbers in parentheses denote t-ratios; they are based on robust standard errors in columns (1) through (6).

PWT is the data source for columns (1) through (6). Column (7) includes 12 industrialized countries.

Dependent variable in column (8) is the ratio of PPP exchange rate to official exchange rate.

\footnotetext{
${ }^{4}$ Previous studies have documented the persistence of significant undervaluation of real exchange rates in transition economies. See, for example, De Broeck and Slok (2001) and Egert (2002).

${ }^{5}$ The estimated elasticity of the Balassa-Samuelson relationship is close to that reported in previous studies; see Table IV.1.
} 
11. Based on these estimates, Kazakhstan's long-run real exchange rate may be expected to appreciate further. Since Kazakhstan's economy is projected to grow more quickly than the U.S. economy in real per capita terms over the medium term, the BalassaSamuelson effect implies an appreciation of the long-run "equilibrium" real exchange rate of tenge against the US dollar of about $2 \frac{1 / 4}{4}$ percent a year.

12. A number of caveats and qualifications apply, however, to the estimates of the deviation between the actual and long-run real exchange rate in 2000 and the change in the long-run rate over time. First, deviations of the real exchange rate from PPP are attributable in part to long-term productivity differences (the Balassa-Samuelson effect), but near-term movements in the exchange rate depend on a variety of other factors - including capital flows, cyclical developments, and fiscal policy. Second, the estimated BalassaSamuelson effect accounts for only about half of the variability across countries of real exchange rate deviations from their "equilibrium" level, implying that other factors have considerable importance. Third, the PPP data in PWT are themselves subject to measurement errors; thus, the estimates for any single country must be treated with caution.

\section{Long-run Prospects for the Tenge's Real Exchange Rate}

13. The estimates reported above suggest that the tenge will continue to appreciate in real terms against the dollar over the longer term. During 2001-04, with the tenge appreciating substantially in real terms against the U.S. dollar, almost one half of the estimated deviation from the estimated long-run level in 2000 was corrected. On average half of the estimated deviation between the actual and long-run real exchange rate at any point in time will be closed over the subsequent decade (Frankel, 2005). If one half of the gap remaining at end-2004-52 percent - is to be closed over the next decade, this would imply an annual real appreciation of about $2 \frac{1}{2}$ percent. $^{7}$

14. Since the long-run real exchange rate is also appreciating, the implied long-term real appreciation of the actual exchange rate will be higher. In particular, given the estimated effect of the growth differential, the average annual real appreciation of the tenge

\footnotetext{
${ }^{6}$ Over the next decade, Kazakhstan's real per capita GDP is expected to grow at an annual rate of 8.1 percent, compared with 2.4 percent for the United States. The estimated annual appreciation of the long-run real exchange rate may be obtained by multiplying 0.394 (the estimated coefficient) by 5.7, the annual growth differential (which proxies the productivity differential) between Kazakhstan and the United States.

${ }^{7}$ Of the estimated deviation of 66 percent in 2000, 28 percentage points had been corrected by end-2004. However, the long-run real exchange rate implied by the Balassa Samuelson effect appreciated by an estimated $13 \frac{1}{2}$ percentage points on a cumulative basis during 2001-04.
} 
would be about $2 \frac{1}{4}$ percentage points higher. Hence, the tenge may be expected to appreciate by an average of $43 / 4$ percent a year in real terms against the dollar over the medium term.

\section{The "equilibrating" real appreciation can be achieved through nominal} appreciation or higher inflation (relative to U.S. inflation). As the operating exchange rate regime is a managed float, sufficient nominal appreciation of the tenge could be undertaken to achieve the equilibrating real appreciation. Alternatively, if nominal appreciation is resisted, the real appreciation may be postponed somewhat but will eventually take place through higher inflation. Indeed, the estimate above suggests that with no nominal exchange rate flexibility in the nominal tenge-dollar exchange rate, average annual CPI inflation would be over 8 percent in the near term (given current U.S. inflation of about $31 / 2$ percent) and over 7 percent over the medium term (given projected longer-term U.S. inflation of $2^{1 / 2}$ percent), in the absence of other-including cyclical and fiscal-effects. If fiscal policy is expansionary, as at present, or if the economy overheats, the implied rate of inflation in Kazakhstan under a relatively inflexible exchange rate regime could be significantly higher, and may prove very costly to reverse.

\section{Costs of Higher Inflation}

16. While limiting nominal appreciation may slow the real appreciation of the tenge in the near term, the costs of higher inflation over the medium term need to be assessed. In this context, lessons from past macroeconomic developments in Kazakhstan, as well as experience from other countries, is relevant.

\section{The decline in inflation in Kazakhstan over the past decade has been} accompanied by strong macroeconomic performance. There has been a brisk rise in money demand, reflected in sustained rapid remonetization. The ratio of credit to GDP has improved considerably (see Chapter III), supporting investment and further economic growth. There has also been a steady decline in dollarization, reflecting increased confidence in the tenge. While it is difficult to assess how much of the improvement in macroeconomic prospects has been due to the improved inflation performance, a marked pickup in inflation could risk a reversal of these favorable trends.

18. Cross-country evidence suggests that high inflation results in lower growth, although the threshold for high inflation in most studies is rather high. Fischer (1993), for example, found that high inflation is harmful to growth, though growth gains are negligible once inflation is brought down to single-digit levels. Bruno and Easterly (1998) found that long-run growth is lower if the inflation rate exceeds 40 percent per annum. Nevertheless, the empirical evidence also shows strong persistence of inflation, and the process of disinflation is costly and takes time.

19. More recent studies find that adverse growth effects can materialize at a much lower inflation threshold. Khan and Senhadji (2001), in particular, found that inflation rates 
exceeding 1-3 percent in industrial countries and 11-12 percent in developing countries would lower growth. ${ }^{8}$ While Kazakhstan's inflation rate under a relatively fixed exchange rate regime would likely remain below the relevant thresholds for growth in the absence of other factors - beyond the long-run equilibrating behavior of the real exchange rate - the presence of cyclical and/or other effects could push up inflation close to (or beyond) the threshold.

\section{Recent empirical evidence suggests an even lower threshold beyond which} inflation has an adverse impact on financial deepening. Using cross-country time series data, Khan, Senhadji, and Smith (2001) found that, controlling for other effects, countries with annual inflation rates in excess of 6 percent experienced slower financial deepening, measured as the ratio of private credit to GDP. Hence, if Kazakhstan were to adopt a relatively fixed exchange rate regime, the equilibrating behavior of the real exchange rate could push up inflation to levels that can affect adversely the ongoing process of financial deepening.

\section{E. Conclusions}

21. The real exchange rate of the tenge against the dollar can be expected to appreciate toward its long-run "equilibrium" level. Estimates of the deviation of current prices from their long-run PPP level, together with the estimated impact of relative productivity differentials, suggest that the real appreciation of the tenge could average $43 / 4$ percent a year over the medium term, and that expansionary fiscal policy or cyclical pressures would imply significantly greater appreciation. Accepting this real appreciation through higher inflation rather than nominal exchange rate flexibility could be costly, as it would risk affecting the process of financial deepening underway in Kazakhstan and could also result in a negative effect on growth.

\footnotetext{
${ }^{8}$ An earlier study covering transition economies - Christofferson and Doyle (2000) estimated the threshold at 13 percent.
} 


\section{References}

Aiyar, Shekhar and Carl-Johan Dalgaard, 2005, "Total Factor Productivity Revisited: A Dual Approach to Development Accounting," IMF Staff Papers, Vol.52, no. 1, p. 82-102.

Balassa, B., 1964, “The Purchasing Power Parity Doctrine: A Reappraisal," The Journal of Political Economy, vol.72, no. 6, pp. 584-596.

Bergin, Paul, Reuven Glick, and Alan M. Taylor, 2004, "Productivity, Tradability, and the Long-Run Price Puzzle,” NBER Working Paper no. 10569 (Cambridge, Mass: National Bureau of Economic Research).

Bruno, Michael and William Easterly, 1998, "Inflation Crisis and Long-run Growth," Journal of Monetary Economics, Vol. 41, pp. 3-26.

Choudhri, Ehsan U, and Mohsin S. Khan, 2004, "Real Exchange Rates in Developing Countries: Are Balassa-Samuelson Effects Present?” IMF Working paper WP/04/188 (Washington: International Monetary Fund).

Christoffersen, Peter and Peter Doyle, 2000,'From Inflation to Growth, Eight Years of Transition," Economics of Transition, Vol. 8, no. 2, pp. 421-451.

De Broeck, Mark, and Torsten Slok, 2001, "Interpreting Real Exchange Rate Movements in Transition Countries," IMF Working paper WP/01/156, (Washington: International Monetary Fund).

Edwards, Sebastian, and Miguel A. Savastano, 1999, "Exchange rates in Emerging Economies: What Do We Know? What Do We Need to Know?.” NBER Working Paper no. 7728 (Cambridge, Mass: National Bureau of Economic Research).

Egert, Balazs, 2002, "Investigating the Balassa-Samuelson Hypothesis in the Transition, Do Understand What We See? A Panel Study" "Economics of Transition, Vol. 10, no. 2, pp. 273-309.

Fisher, Stanley , 1993, “The Role of Macroeconomic Factors in Growth," Journal of Monetary Economics, Vol. 32, pp. 485-512.

Frankel, Jeffrey, 2005, “On the Renminbi: The Choice Between Adjustment Under a Fixed Exchange Rate and Adjustment Under a Flexible Rate," NBER Working Paper no. 11274 (Cambridge, Mass: National Bureau of Economic Research).

Froot, Kenneth A. and Kenneth Rogoff, 1995, "Perspectives on PPP and Long-run Real Exchange Rates," in Handbook of International Economics. G. Grossman and K. Rogoff, eds. (Amesterdam: North-Holland). 
Khan, Mohsin S, and Abdelhak S. Senhadji, 2001, "Threshold Effects in the Relationship Between Inflation and Growth," IMF Staff Papers, Vol. 48, no. 1, pp. 1-21

Khan, Mohsin S, Abdelhak S. Senhajdi and Bruce D. Smith, 2001, "Inflation and Financial Depth," IMF Working Paper 01/44.

Rogoff, K, 1996, “The Purchasing Power Parity Puzzle," Journal of Economic Literature, Vol. 34, pp.647-68.

Taylor, Alan M, and Mark P. Taylor, 2004,"The Purchasing Power Parity Debate" The Journal of Economic Perspectives, Fall, Vol. 18, no. 4, pp. 135-158. 